\title{
Too many cooks spoil the broth: on the impact of external advisors on mergers and acquisitions
}

\author{
Killian J. McCarthy ${ }^{1}$ D . Florian Noseleit ${ }^{1}$
}

Received: 24 August 2020 / Accepted: 19 April 2021 / Published online: 27 September 2021

(c) The Author(s) 2021

\begin{abstract}
Almost $60 \%$ of mergers and acquisitions are concluded with the aid of multiple third-party advisors. While there has been work on the impact of advisors, the theoretical and empirical implications of using multiple advisors remain unclear. Using insights from the "cheap talk" literature, we derive hypotheses on the impact of multiple advisors. Expanding upon this, we then consider the moderating impact of advisor reputation/quality and deal timing (in terms of merger wave periods vs. nonmerger wave periods), as factors that both the cheap talk and the literature on single advisors highlight as relevant. We test our hypotheses using a sample of 10,544 large US acquisitions, and evaluate the impact of advisors using an event study and abnormal returns. Our results support a value-creating role for single advisors-we find that deals with single advisors create a higher expectation of value-creationbut find little support for the use of multiple advisors. Furthermore, we show that the moderating effect of advisor reputation, and deal timing, are contingent on the number of advisors. In doing so, we make a number of academic and practical contributions to the discussion of advisors in mergers and acquisitions.
\end{abstract}

Keywords Mergers · Acquisitions · External advisors $\cdot$ Cheap talk $\cdot$ Herd behaviour $\cdot$ Merger waves $\cdot$ Reputation $\cdot$ Top tiers $\cdot$ Event study $\cdot$ Abnormal returns

\section{Introduction}

Mergers and acquisitions are legally and financially complex events, subject to risk, uncertainty, and information asymmetries (King et al. 2020). ${ }^{1}$ It is hardly surprising, then, to learn that most are concluded with the assistance of external advisor; that is, with the aid of a specialist third party firms (Francis et al. 2006).

\footnotetext{
1 While technically different, the literature uses the terms 'mergers' and 'acquisitions' interchangeably, because the outcome is similar. We follow that practice.

Killian J. McCarthy

k.j.mccarthy@rug.nl

1 Faculty of Economics and Business, University of Groningen, Groningen, The Netherlands
} 
Advisors, the literature suggests, are better at identifying better acquisition targets, and are able to create more value with them (e.g., Bowers and Miller, 1990). ${ }^{2}$ Advisors should have more specialist knowledge regarding the 'how to' of acquisitions and should be able to reduce more of the information asymmetries between the target and the acquirer (e.g. Servaes and Zenner 1996), but also between dealinsiders and outsiders (e.g. Bharadwaj and Shivdasani 2003). Advisors should have superior experience and negotiation skills, which should ensure that their client, the acquirer, captures a greater share of the synergies (e.g., Bao and Edmans 2011). And finally, because the advisors' reputation is on the line with each acquisition, advisors should have strong incentives only to complete deals that add value to the acquirer (e.g., Ismail 2010). Advisors, in other words, should reduce acquisition risk and should increase acquisition value and performance (Servaes and Zenner 1996).

Surprisingly, however, most of the evidence does not support a value-enhancing role for external advisors (e.g., Rau 2000; Hunter and Jagtiani 2003; Da Silva Rosa et al. 2004; Walter et al. 2005; De Jong et al. 2008; Becher et al. 2010). Most research suggests that advisors have a zero or negative effect on acquisition performance and, because advisor fees are typically tied to deal values, research shows that advisors have a positive effect on the price (and/or premium) paid by the acquirer (Russo and Perrini 2006). Scholars have speculated that this may mean that advisors have stronger incentives to complete deals quickly, to 'get paid', than they do to deliver real value to the acquirer's shareholder (e.g., McLaughlin 1990; Hunter and Jagtiani 2003; Allen et al. 2004; Kolasinski and Kothari 2008; Becher and Juergens 2010). Advisors, therefore, have been cast as "guileful, manipulative, and self-serving" (Hayward 2003, p783), and most of the research on advisors has focused, from an agency perspective, on inducing advisors to create value (e.g., Rau 2000).

But perhaps this is unfair. Although there are exceptions (e.g., Hunter and Jagtiani 2003; Rasedie and Srinivasan 2011), the existing research has tended to discuss advisors in a binary sense, comparing deals with advisors to those without (e.g., Servaes and Zenner 1996; Russo and Perrini 2006). The reality, however, is that not only are most deals are concluded with the aid of 'an' advisor but, according to our data, up to $60 \%$ of deals are completed with the aid of 'multiple' advisors. Takeda Pharmaceutical, for example, acquired Shire, in March 2018, not with the aid of 'an' external advisor, but with the aid of 27 advisors. The theoretical and empirical implication of using multiple advisors, however, remains unclear; one idiom suggests 'the more the merrier', the other that 'too many cooks spoil the broth'.

In this paper, we explore the impact of advisors by distinguishing, empirically and theoretically, between situations with one and multiple advisors. We derive our expectations on the impact of multiple advisors using insights from a group of game theoretical models, referred to as the "cheap talk" literature (Crawford and Sobel 1982; Krishna and Morgan 2001; Ottaviani and Sørensen 2006). This explores how information can be transmitted between experts (such as an advisor) and decisionmakers (such as an acquirer) when the expert and the decision-maker have different

\footnotetext{
${ }^{2}$ In this paper, we consider the role of advisors from the perspective of the acquirer. 'Better' therefore, should be understood to mean that the deal adds more value to the acquiring firm.
} 
biases (or preferences). Applying this literature to the context of an acquisition, we argue that-because: (1) all advisors share a 'deal-completion bias', ${ }^{3}$ (2) the information provided by advisors is not public; and (3) managers of the acquiring firm share an optimism bias ${ }^{4}$ and can keep hiring advisors until they find one that will share their bias-more advisors will not create more acquisition value.

Having established this baseline, and having shown the relevance of the cheap talk lens, we then explore the insights offered by the cheap talk concept of herding. Herding is what happens when individuals act collectively without centralized direction (Crawford and Sobel 1982; Krishna and Morgan 2001). It is one of the key concepts in the cheap talk literature. Applied to advisors in an acquisitions context, we argue that herding will moderate the impact of multiple advisors in two ways.

First, and building upon the suggestion that advisor quality should matter (e.g., Bowers and Miller 1990; McLaughlin 1992), we consider the moderating role of including a 'top' advisor on a team of multiple advisors. The cheap-talk literature suggests that advisors are likely to 'herd' together when the decision-maker (the manager) can't separate the contributions of individual advisors. Based on this, we hypothesize that advisor reputation will only positively affect the value of a single advisor. In other words, we hypothesise that advisor quality will not affect acquisition performance when a top quality advisor is included in a team of advisors.

Second, building upon the suggestion that deal-timing matters (e.g., McNamara et al. 2008; Moeller et al. 2005), we consider the moderating role of a deal being concluded during a merger wave; that is, an intensive period of deal-making, characterised by overly optimistic markets and managers (Rhodes-Kropf and Viswanathan 2004; McCarthy et al. 2016), and significant herd behaviour (Schenk 1996; Bouwman et al. 2009). The cheap-talk literature suggests that herd behaviour will reduce the expert's willingness to transfer information, and optimism means that managers will be incentivized to keep hiring advisors until an advisor is found who will share their optimism. Based on this reasoning, we suggest that merger waves will further reduce the value of having multiple advisors, relative to the situation of having a single advisor. In other words, we hypothesise that the effect of multiple advisors will become even more negative in the context of a merger wave period.

We test our hypotheses using a sample of 10,544 large, US acquisitions, in the period 1990-2012. We use an event study (MacKinley 1997), which is commonly used in acquisition research (Zollo and Meier 2008), to describe how the stock market reacts to the announcement of each acquisition. We interpret the reaction as a measure of expected performance or expected value creation (Welch et al. 2020). We interpret our results in the light of interviews conducted at a large advisory firm.

Our results provide a number of interesting insights. Descriptively, we provide insights on the use of advisors in acquisitions. We report, for example, that in 1990 the average deal had 2.3 advisors, and only $9.5 \%$ used 5 or more advisors, but by

\footnotetext{
${ }^{3}$ Eighty-percent of advisor fees are linked to deal completion (McLaughlin 1990, 1992). It is reasonable to assume that advisors will have a preferenece for completing deals.

4 If the manager of the acquiring firm proposes an acquisition, and recruits advisors on it, then it is reasonbale to assume that (s)he will believe that the deal will create value.
} 
2009 the average deal had 4 advisors, and 38\% of deals had 5 or more advisors. Empirically, we report that ceteris paribus, the market responds positively to the announcement of deals that employ one advisor-in anticipation of value creationand negatively to the announcement of deals with multiple advisors-in anticipation of value destruction. We also find support for the hypothesized moderation effects regarding the differential impact of advisor reputation and merger waves.

Our paper makes a number of contributions. Theoretically, we contribute by exploring the mechanisms that distinguish between cases with one and multiple advisors, and by considering the way advisor reputation and merger waves affect these mechanisms. In doing so, we integrate different streams of literature and provide a richer view of the field. Empirically, and by demonstrating that advisors create value-in the sense that deals with one advisor provoke a positive reaction by the market in expectation of superior post-acquisition value creation-we support the managers' choice to hire advisors and vindicate the advisory profession too. We show that advisors are not "guileful, manipulative, and self-serving" (Hayward 2003, p783), but teams of advisors simply become victims of well-known "cheap talk' mechanisms. Both contributions, we suggest, open up avenues for additional research.

Importantly, our findings offer practical insights too. Globally, advisors earn something in the regionof $\$ 40$ billion per year on acquisitions. ${ }^{5}$ Given that our results-which suggest that deals with a single advisor create the most value- the implication is that managers could and should be able to save millions, simply by reducing the number of advisors that they contract on each acquisition.

\section{Background}

\section{1 (External) advisors $^{6}$}

Advisors are specialist third-party firms, hired by the target and/or the acquirer, to facilitate an acquisition (Francis et al. 2006; Russo and Perrini 2006).

Industry practitioners distinguish between two types of (pre-acquisition) advisors: legal advisors-which includes law firms like Latham \& Watkins and Davis Polk and Warwell - and financial advisors-a more heterogenous group that includes accountants, valuers, and investment banks, like Goldman Sachs and Morgan Stanley. Table 1 provides an overview of the categories. It lists the largest 25 advisors, in each category, ranked in terms of the total target value for all acquisitions completed, globally, in the period Jan 1st 2000 to Jan 1st 2021. It reports the number of deals done by each advisor, the advisor's market share in the category, and, interestingly, the percentage of deals that do not use financial (17\%) or legal (19\%) advisors.

\footnotetext{
5 Annual estimates based on Thomson Reuter's half-yearly estimates, as reported here: http://prod-uppimage-read.ft.com/3b08df8e-cf53-11e8-a9f2-7574db66bcd5

6 Much of the information in this section is based on our interviews with M\&A advisors.
} 
Table 1 The advisory industry

\begin{tabular}{|c|c|c|c|c|}
\hline \multirow[t]{2}{*}{ Rank } & \multicolumn{4}{|l|}{ Financial advisor } \\
\hline & Name & Value of targets (\$Mil) & Mkt. share & Number of deals \\
\hline 1 & Goldman Sachs \& Co & $17,393,185.97$ & 28.9 & 8315 \\
\hline 2 & Morgan Stanley & $14,557,245.97$ & 24.1 & 7319 \\
\hline 3 & JP Morgan & $13,571,431.30$ & 22.5 & 8038 \\
\hline 4 & BofA Securities Inc & $11,556,776.44$ & 19.2 & 6399 \\
\hline 5 & Citi & $11,125,364.28$ & 18.5 & 6387 \\
\hline 6 & Credit Suisse & $8,281,803.13$ & 13.7 & 6346 \\
\hline 7 & UBS & $6,740,944.75$ & 11.2 & 5356 \\
\hline 8 & Deutsche Bank & $6,711,756.17$ & 11.1 & 4890 \\
\hline 9 & Barclays & $6,667,114.04$ & 11.1 & 3557 \\
\hline 10 & Lazard & $6,107,154.66$ & 10.1 & 5486 \\
\hline 11 & Rothschild \& Co & $4,538,279.21$ & 7.5 & 6541 \\
\hline 12 & Evercore Partners & $3,546,861.18$ & 5.9 & 1996 \\
\hline 13 & BNP Paribas SA & $2,636,060.43$ & 4.4 & 2883 \\
\hline 14 & Nomura & $2,584,541.65$ & 4.3 & 3837 \\
\hline 15 & Centerview Partners LLC & $2,268,804.80$ & 3.8 & 504 \\
\hline 16 & HSBC Holdings PLC & $1,906,759.27$ & 3.2 & 1724 \\
\hline 17 & RBC Capital Markets & $1,896,115.58$ & 3.1 & 2709 \\
\hline 18 & Jefferies LLC & $1,332,386.03$ & 2.2 & 2994 \\
\hline 19 & Houlihan Lokey & $1,319,150.97$ & 2.2 & 4966 \\
\hline 20 & PJT Partners Inc & $1,317,023.01$ & 2.2 & 760 \\
\hline 21 & Macquarie Group & $1,310,165.00$ & 2.2 & 2430 \\
\hline 22 & Moelis \& Co & $1,286,313.48$ & 2.1 & 1445 \\
\hline 23 & Perella Weinberg Partners LP & $1,171,593.89$ & 1.9 & 647 \\
\hline 24 & Greenhill \& Co, LLC & $1,167,358.07$ & 1.9 & 893 \\
\hline \multirow[t]{4}{*}{25} & Societe Generale & $1,149,138.78$ & 1.9 & 1379 \\
\hline & Subtotal with Financial Advisor & $49,823,600.88$ & 82.7 & 198,798 \\
\hline & Subtotal without Financial Advisor & $10,456,523.56$ & 17.3 & 669,863 \\
\hline & Industry Total & $60,280,124.44$ & 100.0 & 868,661 \\
\hline \multirow[t]{2}{*}{ Rank } & \multicolumn{4}{|l|}{ Legal advisor } \\
\hline & Name & Value of targets (\$Mil) & Mkt. share & Number of deals \\
\hline 1 & Sullivan \& Cromwell & $9,056,562.19$ & 15.0 & 3262 \\
\hline 2 & Skadden & $8,223,831.90$ & 13.6 & 4886 \\
\hline 3 & Simpson Thacher \& Bartlett & $6,910,236.27$ & 11.5 & 3057 \\
\hline 4 & Freshfields Bruckhaus Deringer & $6,470,469.49$ & 10.7 & 5759 \\
\hline 5 & Davis Polk \& Wardwell & $6,466,077.59$ & 10.7 & 2621 \\
\hline 6 & Wachtell Lipton Rosen \& Katz & $6,311,913.71$ & 10.5 & 1605 \\
\hline 7 & Cleary Gottlieb Steen \& Hamilton & $6,025,050.43$ & 10.0 & 2956 \\
\hline 8 & Latham \& Watkins & $5,715,449.93$ & 9.5 & 7316 \\
\hline 9 & Linklaters & $5,704,850.04$ & 9.5 & 6395 \\
\hline 10 & Cravath, Swaine \& Moore & $5,169,849.48$ & 8.6 & 1393 \\
\hline
\end{tabular}


Table 1 (continued)

\begin{tabular}{|c|c|c|c|c|}
\hline \multirow[t]{2}{*}{ Rank } & \multicolumn{4}{|l|}{ Legal advisor } \\
\hline & Name & Value of targets (\$Mil) & Mkt. share & Number of deals \\
\hline 11 & Shearman \& Sterling LLP & $5,103,129.16$ & 8.5 & 3435 \\
\hline 12 & Clifford Chance & $4,823,055.74$ & 8.0 & 6705 \\
\hline 13 & Weil Gotshal \& Manges & $4,638,889.36$ & 7.7 & 4206 \\
\hline 14 & Allen \& Overy & $4,343,019.20$ & 7.2 & 6048 \\
\hline 15 & White \& Case LLP & $3,733,646.07$ & 6.2 & 5009 \\
\hline 16 & Jones Day & $3,536,323.58$ & 5.9 & 10,085 \\
\hline 17 & Fried Frank Harris Shriver \& Jacobson & $3,245,500.41$ & 5.4 & 1480 \\
\hline 18 & Slaughter and May & $3,227,239.78$ & 5.4 & 1789 \\
\hline 19 & Kirkland \& Ellis & $3,187,778.32$ & 5.3 & 5951 \\
\hline 20 & Debevoise \& Plimpton & $3,121,212.35$ & 5.2 & 1726 \\
\hline 21 & Hogan Lovells & $2,804,615.93$ & 4.7 & 4669 \\
\hline 22 & Baker Mckenzie & $2,771,940.59$ & 4.6 & 6844 \\
\hline 23 & Gibson Dunn \& Crutcher & $2,702,400.86$ & 4.5 & 3029 \\
\hline 24 & Paul, Weiss & $2,651,696.04$ & 4.4 & 2264 \\
\hline \multirow[t]{4}{*}{25} & Dewey \& LeBoeuf LLP & $2,572,966.48$ & 4.3 & 1597 \\
\hline & Subtotal with Legal Advisor & $48,827,277.40$ & 81.0 & 228,668 \\
\hline & Subtotal without Legal Advisor & $11,452,847.05$ & 19.0 & 639,993 \\
\hline & Industry Total & $60,280,124.44$ & 100.0 & 868,661 \\
\hline
\end{tabular}

Financial advisors offer their clients a large set of acquisition-relevant services. Within large financial advisors, like Goldman Sachs and Morgan Stanley, investment bankers help acquirers to select targets-they often, in fact, take the lead in (unsolicited) prospecting for targets - and provide advice on the acquisition strategy. The accountants then conduct financial due diligence and prepare 'pro forma' financial statements, forecasting post-acquisition performance. The valuators use these sorts of inputs to provide the acquirer with a value for the target. And, finally, the investment bankers advise the acquirer on how to raise the necessary finance.

Legal advisors are then contracted to help the target and the acquirer to navigate the complex legal environments that surround acquisitions. They play a particularly important role in international acquisitions, hostile acquisitions, or in acquisitions in regulated industries. They guide the target and/or the acquirer through the acquisitions process, complete legal due diligence, and ensure that the correct paperwork is filed with regulatory authorities, such as the Securities and Exchange Commission (SEC) in the United States, or the European Commission in the European Union.

Both types of advisors are well-compensated for their services. Advisors often charge acquirers a fixed retainer, a fixed advisory fee, and a deal completion fee. The latter is often calculated using the so-called Lehman Scale, which sees advisors get $5 \%$ of the first $\$ 1,000,000$ in target value, $4 \%$ of the second, $3 \%$ for the third, $2 \%$ for the fourth, and $1 \%$ of the remaining total. The Double Lehman Scale doubles the percentages, to $10 \%$, for example, for the first million, and is used in the case of particularly complex acquisitions. As a rule of thumb-and because of the size of the 
acquisitions made by larger public acquirers - it has been suggested that advisors are typically paid somewhere in the region of $1 \%$ of the deal value (Kosnik and Shapiro 1997).

\subsection{On the impact of advisors}

\subsubsection{A value creating role for advisors}

The literature identifies a number of ways in which advisors can create value (Rau 2000; Hunter and Jagtiani 2003; Da Silva Rosa et al. 2004; De Jong et al. 2008).

The 'better deal' hypothesis suggests that, as professional 'matchmakers' (Russo and Perrini 2006. p.51), advisors can identify better targets, that add more value to the acquiring firm, and generate greater synergies at a lower cost (Bowers and Miller, 1990; Thomas 1995; Servaes and Zenner 1996; Ismail 2010). Advisors, this literature suggests, bring better deals to the attention of their clients/the acquirers.

The 'information asymmetries' hypothesis (Bowers and Miller, 1990; Servaes and Zenner 1996; Angwin 2001; Kisgen et al. 2009; Becher et al. 2010) suggests that advisors not only reduce information asymmetries between the target and the acquirer, "which can be severe when assets are difficult to value, [or] when the target is highly diversified" (Jong et al. 2008. p4), ${ }^{7}$ but that they also play a certification role, helping to reduce information asymmetries between managers, shareholders, and outside investors (Bharadwaj and Shivdasani 2003; Allen et al. 2004). In support of this a number of studies show that advisors are more likely to be used in complex deals. Advisors, this literature suggests, help their clients to better understand their targets, and, therefore, advisors can help their clients to pay the right price.

The 'better negotiator' hypothesis suggests that advisors provide acquirers with valuable anonymity in the preliminary stages of the acquisition before negotiations officially begin (Diamond and Maskin 1979; Grossman and Hart 1980; Rasedie and Srinivasan 2011). ${ }^{8}$ With their superior negotiation skills, advisors also ensure that, during the negotiation process, their clients capture a greater share of the acquisition gains (Bowers and Miller, 1990; Thomas 1995; Bao and Edmans 2011). Advisors, this literature suggests, help their clients to 'feel-out' the option, before committing, and once committed, advisors help their clients to capture the greater benefits.

Finally, the 'reputation hypothesis' suggests that, because an advisor's reputation matters (Bowers and Miller, 1990), advisors are not only incentivized to initiate deals that create value for the acquiring firm, but they have a strong incentive to monitor the deal too, to ensure that that value is created. In support of this, Kale et al. (2003) show that shareholders gain more synergies when their advisors have a higher reputation. Advisors, this literature suggests, should thus involve themselves

\footnotetext{
7 In support of this, Servaes and Zenner (1996) show that advisors are more likely to be retained in more complex transactions, characterised by significant asymmetric information.

8 Anonymity allows bidders to explore the possibility of an acquisition, without provoking a market reaction and without losing face in cases where advances are rejected by the target.
} 
in deals that create value for their clients, because the advisor's reputation is on the line too.

\subsubsection{A value destroying role for advisors}

Surprisingly, however, the majority of the literature does not support a value-creating role for advisors (Bowers and Miller 1990; Rau 2000; Hunter and Jagtiani 2003; Da Silva Rosa et al. 2004; Walter et al. 2005; De Jong et al. 2008; Becher et al. 2010). Servaes and Zenner (1996) for example, find no benefit to hiring advisors, using a sample of deals completed with and without advisors in the period 1981 to 1992.

A number of reasons have been forwarded to explain why. The 'passive execution' hypothesis, for example, suggests that advisors are "simply 'execution houses' who undertake deals as instructed by the client", without adding any value (Bao and Edmans 2011, p.2287). This implies that the advisors do not add value to the deal, but only costs, and therefore the advisory industry itself "is mainly a deadweight loss' (Bao and Edmans 2011, p.2287). Advisors, this literature suggests, do not add value, because they do not, for example, use their skills as better negotiators, or as better match-makers, because advisors simply do what their client instructs them to do.

The 'deal complexity' hypothesis (Russo and Perrini 2006), suggests that advisors use a 'land and expand' strategy (see e.g., Forbes Magazine, 2014), ${ }^{9}$ to push products and services that increase deal complexity, and advisory fees. In support of this, Russo and Perrini (2006), find, that ceteris paribus, deals completed without advisors paid only a fraction of the premium on the purchase price paid by deals with advisors. Advisors, this literature suggests, do not add value, because they push clients into unnecessarily complex deals, to sell unnecessary (and expensive) services.

Finally, the 'deal completion' hypothesis suggests that, because advisor reputation depends not on the quality of the deals done but on the quantity (Rau 2000; Rau and Rodgers 2002; Hunter and Jagtiani 2003), ${ }^{10}$ and because as much as $80 \%$ of the advisors' fees are contingent on deal completion (McLaughlin 1990; 1992), advisors not only push acquirers into unnecessary deals (Eccles and Crane 1988; Agrawal et al. 2011) but push them to complete those deals at any cost (Rau 2000; Allen et al. 2004). In support of this, research has shown that advisors provide their clients with biased reports and outlooks (Cain and Denis 2008; Becher et al. 2010) in an effort to maximise fees (Kolasinski and Kothari 2008), and to ensure that the deal is completed (Becher and Juergens 2010). Advisors, this literature suggests, do not add value, because they

\footnotetext{
9 Forbes Magazine (November 20, 2014): "Sell more with a land-and-expand strategy", by Josh Linkner, and available at https://www.forbes.com/sites/joshlinkner/2014/11/20/sell-more-with-a-land-and-expandstrategy/\#58005f2151a6

${ }^{10}$ In the literature, market share in the advisory industry is typically defined in terms of the number of deals completed, and many studies, therefore (see e.g., Rau 2000), discuss the market share of the advisor, rather than the quantity of the deals they conclude.
} 
do not need to add value: advisors are paid to complete deals, and advisor reputation is measured in terms of quantity, rather than quality.

\subsection{On the impact of top advisors}

As with all professions, there are differences in advisor quality. The literature, therefore, distinguishes between high quality - so-called top-tier advisors-and lower quality advisors (Hunter and Walker 1990; Kale et al. 2003; Ma 2007).

Early studies showed that the choice of advisor quality was an important determinant of advisor impact. Hunter and Walker (1990), Michel et al. (1991) and Bowers and Miller (1990), for example, show that high quality or 'top-tier' advisors do better deals. Later, Ma (2007) shows that top-tier advisors are able to identify better deals, by matching target and acquires, and Kale et al. (2003) show that top-tier advisors are also better able to structure those deals, to create higher synergy gains with the deal. Kale et al (2003) also report that acquirers that employ higher reputation advisors than the target also receive a larger share of the total synergy gains from the takeover.

Again, however, the majority of the literature does not support a value-creating role for top-tier advisors. A number of studies find no support for the hypothesis that better advisors do better deals (e.g., Michel et al. 1991; Servaes and Zenner 1996; Rasedie and Srinivasan 2011), but the majority (e.g., McLaughlin 1992; Rau and Rodgers 2002; Ismail 2010) finds that the 'synergistic gains realised by the acquirers declines when top advisors were used' (Hunter and Jagtiani 2003, p.65). Rau (2000) and Walter et al (2005) demonstrate this phenomenon in the US context, Da Silva Rosa et al. (2004) show it in the Australian one, and Rasedie and Srinivasan (2011) show it in the Canadian context. Top advisors, the research concludes, are more likely to complete deals faster, and to charge higher fees (Rau 2000; Ismail 2010), than they are to deliver greater abnormal returns to the acquirer (Walter et al. 2005).

\subsection{On the impact of multiple advisors}

Anecdotal evidence suggests that many acquisitions are not concluded with the aid of 'an' advisor, but with the aid of multiple advisors. Presumably, the teams of advisors that this results in can include top advisors. The existing literature, however, has largely ignored the topic of multiple advisors; only a few studies have touched upon the topic empirically (see e.g., Hunter and Jagtiani 2003; Rasedie and Srinivasan 2011) ${ }^{11}$, and little to no work has been done to theoretically derive expectations on the impact of single versus multiple advisors. We aim to fill these gaps, by first theorising and by then empirically testing the impact of single versus multiple advisors.

\footnotetext{
11 Hunter and Jagtiani (2003) use the number of advisors as a control variable, in their study of advisor choice, fees, and effort in mergers and acquisitions. They show that the number of advisors increases the probability and speed of deal completion, the post-acquisition gains to the acquirer, and the level of fees paid. Rasedie and Srinivasan (2011) introduce multiple advisors as a dummy variable, in their study of advisor reputation, and show that "multiple advisors increase the time for completions as coordination becomes difficult" (p.39).
} 


\section{Hypotheses}

\subsection{Multiple advisors and cheap talk}

We derive our expectations on the impact of multiple advisors using insights from a group of game theoretical models, subsumed under the label of the "cheap talk" literature (Crawford and Sobel 1982; Krishna and Morgan 2001; Ottaviani and Sørensen 2006). This literature explores how information can be transmitted when communication is direct and costless and when an expert (an advisor) and a decision-maker (an acquirer) have divergent preferences or biases. The literature highlights three conditions under which employing multiple advisors could be beneficial or disadvantageous, relative to the situation of employing a single advisor.

First, the literature highlights the importance of transparency. Bourjade and Jullien (2011), for example, show that, in the case of multiple experts, the incentive for any expert to reveal information truthfully is reduced when the expert's information contribution is not public. In the same vein, Li (2010) shows that when the expert's biases are private, the result is "babbling"- that is, sending messages that do not reflect the underlying state-and "partisanship"- that is, sending messages for self-serving purposes. In other words, in situations of private information, multiple advisors will not be beneficial but will be harmful to the decision-maker.

Second, the literature highlights the importance of the advisors' biases. Krishna and Morgan (2001) show that if experts are biased in opposite directions, then it is always beneficial for the decision-maker to consult both. Battaglini (2004) also shows that, if all experts are perfectly informed and all biases are known, the number of experts increases the precision and truthfulness of the messages that can be extracted. In other words, in situations where experts are biased in opposing directions, or in situations where experts are imperfectly informed, multiple advisors will be beneficial. Krishna and Morgan (2001) also show, however, that when experts have shared (or 'like') biases, then it is never beneficial for the decision-maker to consult more than one expert, because in such a case, the decision-maker will not receive better information. Zapechelnyuk (2013) adds to this discussion, by considering the possibility that biased experts collude with each other, and show that, in such situations, it is even more difficult for decisionmakers to stimulate truthful information transfer from advisors. In other words, in situations where experts are biased in the same direction, and likely to collude, multiple advisors will not be beneficial to the decision-maker.

Third, the literature highlights the importance of the decision maker's bias. Mullainathan and Shleifers (2005), for example, show that receivers with shared common bias do not obtain accurate information from competing senders. Extending this, Ishida and Shimizu (2012) show that biased decision-makers, who can hire additional experts, will continue to hire experts until they find the one who shares their bias rather than follow the advice of the first expert, should that expert have an opposite bias. Since experts in such a situation have 
little incentive to report truthfully, in the expectation that their report will not be considered, the implication is that biased decision-makers reduce the transfer of honest information. In other words, when the decision-maker is biased, multiple advisors will not be beneficial.

Consequently, the impact of multiple experts depends strongly on a variety of factors, such as the nature of bias of managers and the expert advisors, their level of information about the consequences, and their incentives to reveal information.

\subsection{Multiple advisors and cheap talk in an M\&A context}

A number of features of the acquisition context led us to suggest that multiple advisors will have a harmful effect, relative to the case of a single advisor.

Firstly, and because the literature suggests that up to $80 \%$ of advisor fees are contingent on deal completion (McLaughlin 1990; 1992), we suggest that advisors will share a deal-completion bias. Krishna and Morgan (2001) suggest, however, that when advisors share a 'like bias' then it is never beneficial for the decision-maker to consult additional advisors, and as Zapechelnyuk (2013) shows, when advisors share a like-bias, they are more likely to collude. The implication then is that multiple advisors may not only push acquirers into unnecessary deals, as suggested by Eccles and Crane (1988) and Agrawal et al (2011), but may push them to complete those deals at any cost, as suggested by Rau (2000) and Allen et al (2004). As one advisor told us, in the course of this research, the advisor's job's is "to do get the deals done", it's not the job of one advisor 'to challenge the findings of another', and in support of Cain and Denis (2008) and Becher et al (2010) suggestion that advisors are willing to provide their clients with biased reports and outlooks, we were also told that 'sometimes reports have to be written a bit differently', in order to get deals done. $^{12}$

Next, we suggest that the advisory process is not a transparent one, and the individual contributions of advisors are not easily discernible. In an acquisition involving teams of advisors, 'everyone has his own area', and 'does his own bit', the work is done in 'isolation', and 'more and more via the cloud'. ${ }^{13}$ This not only creates information asymmetries, and adds to the complexity of the deal, but makes it difficult too to attribute specific aspects of the final report to individuals. Bourjade and Jullien (2011) and Li (2010) warn, however, that when advisor biases are private and their contribution is not public, hiring additional advisors results in both "babbling" and "partisanship". Consequently, the fact that the advisory process is not transparent means that multiple advisors will not add additional value, relative to a single advisor.

Finally, the literature suggests that managers share an optimism bias. A long tradition in acquisitions research suggests that managers are overoptimistic (e.g.,Roll 1986; Malmendier and Tate 2008). Overoptimistic managers are overconfident

12 From the set of interviews, with M\&A advisors, conducted for this research.

13 From the set of interviews, with M\&A advisors, conducted for this research. 
in their abilities to create value through acquisitions and are biased towards optimistic acquisition scenarios. A number of implications arise from this fact. First, and as Lavallo and Kahnemann (2003) explain, 'anchoring' - a cognitive bias that leads decision-makers to rely more heavily on initial information-means that overoptimistic managers are unlikely to be 'talked out of' an acquisition. Second, and as Ishida and Shimizu (2012) show, biased decision-makers will continue to hire additional advisors, until they find the one who shares their bias, rather than follow the advice of the first advisor, should the first advisor have an opposite bias. Since experts, in such a situation, have little incentive to report truthfully to the decisionmaker, in the expectation that their report will not be considered, Ishida and Shimizu (2012) suggest that biased decision-makers reduce honest information transfer. Advisors, in such a situation, simply 'have to keep the manager happy'. ${ }^{14}$ Together, however, managerial bias means that multiple advisors will not add additional value.

Thus, because advisors share a deal-completion bias, because the contribution of each advisor is private, and because managers share an optimism bias, the implication, from the cheap talk literature, is that additional advisors will not add additional value.

H1 Single advisors will add more value than multiple advisors.

\subsection{Cheap talk, herd behaviour and top tier advisors}

A number of 'cheap talk' contributions help us to build expectations regarding the potential moderating impact of having a top-tier advisor on the team of advisors.

Firstly, Ottaviani and Sørensen (2006) show that when there is competition among experts, the incentives to 'herd' leads to a situation in which honest information revealing tends not to occur. Interestingly, and "[c]ontrary to naive intuition" they suggest that "experts wishing to be perceived as accurate do not truthfully reveal their private information." (p. 156). The reason is that experts who have incentives to build a reputation may aim to build this reputation by manipulating the transmitted information towards the a priori expected. Secondly, and building on this, Bourjade and Jullien (2011) analyse situations in which experts care for their reputation and are biased simultaneously. They show that in such a situation, asking for additional advice from a second expert is only beneficial if the market can identify the contribution of each expert separately. In this case, a biased but reputationconcerned expert has a lower incentive to hide information because the other expert may reveal it. However, in situations where the market can only identify the joint contribution of both experts - as is the case in the context of an acquisition - the authors show the incentive to report truthfully is reduced. In sum, and based on the suggestions:

14 From the set of interviews, with M\&A advisors, conducted for this research. 
H2 Higher levels of advisor reputation are positively related to the value delivered by an advisor, but only in the case of one single advisor.

Finally, and building upon the suggestion that herd behaviour reduces the benefits of top-tier advisors and may cause multiple advisors to underperform in general, we consider the performance implications of the moderating impact of merger waves as a well-known herding situation (Martynova and Renneboog 2008). We argue that, in the context of an acquisition, herding effects might also influence the impact of advisors on acquisition performance during merger waves. This means that experts' information transfer is driven by group psychology, which has a tendency to deteriorate the link between available information and transferred information during merger waves. The fifth merger wave (1990-2001), for example, ended saw acquirers herd into dot.com acquisitions, due to a shared optimism regarding dot.com targets, and ended with the dot.com crash (McCarthy et al. 2016). A similar dynamic unfolded in the sixth wave (2003-2008), which ended in the financial crisis (McCarthy et al. 2016). Such merger-wave related herd behaviour can consequently reduce experts' willingness to transfer information that is available to them to the decisionmaker, "fearing that their contrarian behavior will damage their reputations [...]" (Scharfstein and Stein 1990, p. 465). Consequently, in situations where herd behaviour tends to be more likely, for example, in the context of merger waves, information transfer between experts and decision-makers can be restrained. This implies that, if expert advice is beneficial for merger performance, this positive impact becomes lower during merger waves. If the advice from multiple experts is negative this negative relationship becomes even more pronounced during waves.

H3 Merger waves negatively moderate the impact of external advisors, and in particular the impact of teams of multiple advisors.

\section{Methods}

\subsection{Sample}

We use Thomson SDC to build our sample. We refine this to include all acquisitions: (1) announced between Jan 1, 1990 and Jan 1, 2012; (2) that do not involve a recapitalization, repurchase, or a spin-off to existing shareholders. We only include acquisitions by: (3) publicly listed; (4) US acquirers; (5) seeking to buy $100 \%$ of the target; (6) with deal value greater than US\$10 million; (7) in which neither the acquirer nor the target is fully or partially owned by public authorities, such as the government; and (8) where the two firms are not part of the same.

\subsection{Dependent}

We use an event study, and calculate the cumulative abnormal return to the acquirer, to described expected value-creation (Brown and Warner 1985; MacKinley 1997). 
In an event study, a pre-event 'estimation window' is defined, and historical data is used to forecast the firm's 'normal' stock price at a future date; this is an expectation of how the firm's stock should have been priced had the event not occurred (McCarthy and Aalbers 2016). Comparing this 'forecast' with 'actual' data on the firm's stock price provides an indication of how the event caused the firm's value to deviate from its expected value. These deviations are referred to as abnormal returns (ARs). Summing these over a pre-defined period of time, known as an 'event window', leads to an expression known as 'cumulative abnormal returns' (CARs).

CARs are often considered a measure of acquisition performance (Welsh et al. 2020); in fact, they are the most commonly used measure of acquisition performance (Zollo and Meier 2008). In reality, they are the market correcting the present value of the acquiring firm, pre-integration, in anticipation of post-integration value creation/destruction. They are, therefore, best described as 'expected performance', or 'expected value creation', based on the collective wisdom of the market.

There is no consensus on what constitutes an appropriate estimation (MacKinley 1997) or event (Martynova and Renneboog 2008) window. The majority of studies make use of a longer estimation window (e.g., McNamara et., 2008), and event windows which are "as short as possible" (McWilliams and Siegel (1997, p. 636)). Consequently, we use an estimation window, of 250 days, measured from 295 days before each event to 45 days before it $[-295,-45]$, and a 3-day estimation windows, measured from 1 day before the announcement, to include information leakages (Asquith 1983), to 1 day after $[-1,+1]$. For robustness checking purposes, we also estimate CARs using a $[-2,+1]$ and a $[-5,+1]$ estimation window. We winsorize the result, between $0.01 \%$ and $99.99 \%$, to reduce the effect of extreme outliers. ${ }^{15}$ All the data necessary to estimate the CARs were collected from DataStream.

\subsection{Independent}

In 10,544 cases we are able to identify the number of advisors to the deal, with the aid of the SDC. We drop the remaining cases, in which no or incomplete information was reported, and do not assume that no mention of an advisor means no advisors. ${ }^{16}$

For each acquisition, we then count the number of advisors to the acquirer (Number of Advisors). Using this data, we compute: (1) a dummy variable (One Advisor), which we set to 1 if the deal has one advisor and set to 0 if the deal has zero or multiple advisors; and (2) a dummy variable (Multiple Advisors) which we set to 1 if the deal has multiple advisors and set to 0 if it has zero or one advisor.

\footnotetext{
${ }^{15}$ By winsorizing between $0.01 \%$ and $99.99 \%$, we set all data below the 0.01 th percentile equal to the 0.01th percentile, and all data above the 99.99th percentile equal to the 99.99th percentile. The estimators that this creates are more robust to outliers, and by winsorizing the data, rather than dropping any outliers, we can make use of the full set of data.

16 We find that there are no statistically significant differences between the 10,544 deals that we include and the 9283 deals that we drop at this stage, in terms of average performance (in terms of CAR1), timing (in terms of Merger Wave), acquirer type (in terms of Market-to-Book Ratio), deal type (in terms of Percentage Cash and the level of internationalisation), and deal complexity (in terms of deal size). More details on these variables follow below.
} 
Finally, for robustness checking purposes, but also because the literature suggests not only that there are different types of advisors (see e.g., Francis et al. 2003; Bao and Edman, 2009; Krishnan and Masulis 2011), but that these different types of advisors bring different skills and share different risks (Russo and Perrini 2006), we use the SDC to count: (1) the number of legal advisors to the acquirer (Number of Legal Advisors) and (2) the number of financial advisors to the acquirer (Number of Financial Advisors). We then create dummy variables to distinguish between deals with one or multiple financial advisors, and one or multiple legal advisors.

\subsection{Moderators}

Advisor Reputation: Research suggests that advisor reputation depends on the quantity of deals made (Rau 2000; Rau and Rodgers 2002; Hunter and Jagtiani 2003). Consequently, Rau (2000) and McLaughlin (1992) identify the top advisors in their sample as a count of the total number of deals made over the sample period. We follow Da Silva Rosa et al. (2004) and Walter et al. (2005) in suggesting that such a static ranking system ignores the dynamics of the advisor. We identify the top 10 advisors in any given year using the total value of deals completed in that year. The necessary information to programme this variable, in terms of deal value per year, was retrieved from the SDC. We identify any deal in which any of the acquirers' advisors were listed as top advisors using a dummy variable. For descriptive reasons, we also record: (1) the number of deals in which the acquirer used a top advisor; (2) the number of deals in which the target used a top advisor; and (3) the number of deals in which both the target and the acquirer used a top advisor.

Merger Waves: There are a number of ways to identify merger waves. We follow the approach introduced by Bowman et al. (2009) and adopted by a range of scholars (e.g. Goel and Thakor 2010; Doukas and Zhang 2016; McCarthy et al. 2016), and use monthly acquisitions data to identify merger waves. Specifically, we first calculate the monthly total deal value for the period. Then correct these for inflation, and finally, we de-trend the data by removing the line of best fit of the previous three years from the real total deal value of the observed month. If the deal value in a specific month is above the average of all months, then we define that month as a 'merger wave' month, and we set a merger wave variable equal to one; otherwise, we set it to zero.

\subsection{Controls}

We control for two sets of acquisition factors - at the firm and deal level—which are known to impact the levels of premiums paid and the level of abnormal returns.

At the firm-level, we control for: (1) the Market-to-Book Ratio of the acquiring firm, using data collected from DataStream, because research shows that glamour firms, with a low market-to-book ratio, make different deals to value firms (Rau and Vermaelen 1998); (2) acquirers' Leverage, measured in terms of total debt, using data collected from DataStream, because research suggests that the 'discipline of debt' impacts acquisition behavior (Jensen 1986); (3) Free Cash Flow to the acquiring firm, defined 
as the acquirers' operating income, minus taxes, interest expense, preferred dividends, and common dividends, all divided by equity, which we estimate using data collected from DataStream, because research suggests that excess liquidity impacts acquisition behavior (Jensen 1986); (4) acquirer acquisition Experience, measured as the number of acquisitions that the acquirer made in the five years prior to the focal deal, which we estimate using data collected from the SDC, because acquisition experience impacts performance (Heleblian and Finkelstein, 1999); and (5) acquirers' Prior Performance, measured using the acquirers' return on assets in the year prior to the acquisition, using data collected from DataStream, because successful firms make better acquirers (McNamara et al. 2008).

At the deal-level we control for: (1) the percentage of the deal paid for in cash (Percent Cash), using data collected from the SDC, because the percentage of cash has been shown to impact abnormal returns (King et al. 2004); (2) International Deals, which we identify using data collected from the SDC and a dummy variable set equal to 1 if the acquirer and the target are in different countries, because international deals encounter the liability of foreignness (Zaheer 1995); (3) Hostile Deals, using data collected from the SDC to create dummy variable set equal to 1 if the deal was hostile or unsolicited, because hostile deals are more complex and tend to underperform (Betton and Eckbo 2000); (4) Related Deals, using data collected from the SDC to generate a dummy variable set equal to 1 if the four-digit SIC codes of the three main lines of business of the target and the acquirer are the same, because related acquisitions outperform unrelated acquisitions (Chatterjee 1986); and (5) Public Targets, using data collected from the SDC to create a dummy indicating public (stock-listed) targets, as distinct from private (non-listed) targets because the different target types perform differently (Conn et al. 2005).

We replace all missing values with the variables' mean value. We use the Shapiro-Wilk test for normality; we use logarithmic transformations in our analysis for variables (Market to Book, Prior Performance Percent Cash, Leverage, Free Cash Flow) that failed this test. Table 2 reports descriptive statistics and correlations.

\subsection{Estimation}

We model the way in which the market reacts to the announcement as:

$$
\begin{aligned}
\text { CAR }_{i t}= & \beta_{0}+\beta_{1} \text { AdvisorVariables }_{i t}+\beta_{j} \text { FirmLevelControls }_{i t} \\
& +\beta_{j} \text { FirmLevelControls }_{i t}+\beta_{j} \text { DealLevelControls }_{i t}+\varepsilon_{i t}
\end{aligned}
$$

where (1) $C A R_{i t}$ is the cumulative abnormal return to firm $i$ in period $t$ on the announcement of the acquisitions; (2) $\beta_{1}$ AdvisorVariables it $_{i t}$ is the set of possible independent variables described above, such as the count variable (No. Acquirer Advisors) indicating the number of advisors, and the two dummy variables, which identify deals with one (One Acquirer Advisor) or more (Multiple Acquirer Advisors) advisors, for firm $i$ in period $t$; (3) $\beta_{j}$ FirmLevelControls $s_{i t}$ is the set of firmlevel controls described above, such as the level of acquirer acquisition experience (Experience) for firm $i$ in period $t$; (4) $\beta_{j}$ DealLevelControls $s_{i t}$ is the set of deal level 
Table 2 Descriptive statistics and correlations

\begin{tabular}{|c|c|c|c|c|c|c|c|c|c|}
\hline & & 1 & 2 & 3 & 4 & 5 & 6 & 7 & 8 \\
\hline 1 & CAR & 1.000 & & & & & & & \\
\hline 2 & $\begin{array}{l}\text { Number of Advi- } \\
\text { sors }\end{array}$ & $\begin{array}{r}-0.061 \\
{[0.000]}\end{array}$ & 1.000 & & & & & & \\
\hline 3 & $\begin{array}{l}\text { (Dummy) One } \\
\text { Advisor }\end{array}$ & {$[0.000]$} & $\begin{array}{r}-0.636 \\
{[0.000]}\end{array}$ & 1.000 & & & & & \\
\hline 4 & $\begin{array}{l}\text { (Dummy) Multiple } \\
\text { Advisors }\end{array}$ & $\begin{array}{r}-0.060 \\
{[0.000]}\end{array}$ & 0.510 & $\begin{array}{r}-0.613 \\
{[0.000]}\end{array}$ & 1.000 & & & & \\
\hline 5 & Top Advisor & $\begin{array}{r}-0.028 \\
{[0.004]}\end{array}$ & $\begin{array}{c}0.376 \\
{[0.000]}\end{array}$ & $\begin{array}{r}-0.249 \\
{[0.000]}\end{array}$ & $\begin{array}{c}0.368 \\
{[0.000]}\end{array}$ & 1.000 & & & \\
\hline 6 & Merger Wave & $\begin{array}{r}-0.004 \\
{[0.652]}\end{array}$ & $\begin{array}{r}-0.050 \\
{[0.000]}\end{array}$ & $\begin{array}{c}0.021 \\
{[0.028]}\end{array}$ & $\begin{array}{r}-0.001 \\
{[0.907]}\end{array}$ & $\begin{array}{r}-0.035 \\
{[0.000]}\end{array}$ & 1.000 & & \\
\hline 7 & Prior Performance & $\begin{array}{c}0.008 \\
{[0.454]}\end{array}$ & $\begin{array}{c}0.031 \\
{[0.003]}\end{array}$ & $\begin{array}{r}-0.034 \\
{[0.001]}\end{array}$ & $\begin{array}{c}0.028 \\
{[0.005]}\end{array}$ & $\begin{array}{c}0.002 \\
{[0.839]}\end{array}$ & $\begin{array}{r}-0.041 \\
{[0.000]}\end{array}$ & 1.000 & \\
\hline 8 & $\begin{array}{l}\text { Market to Book } \\
\text { Ratio }\end{array}$ & $\begin{array}{r}-0.002 \\
{[0.828]}\end{array}$ & $\begin{array}{r}-0.005 \\
{[0.616]}\end{array}$ & $\begin{array}{r}-0.006 \\
{[0.530]}\end{array}$ & $\begin{array}{r}0.009 \\
{[0.372]}\end{array}$ & {$[0.147]$} & $\begin{array}{c}0.011 \\
{[0.266]}\end{array}$ & $\begin{array}{r}-0.001 \\
{[0.957]}\end{array}$ & 1.000 \\
\hline 9 & Percent Cash & $\begin{array}{r}-0.029 \\
{[0.045]}\end{array}$ & $\begin{array}{r}-0.014 \\
{[0.339]}\end{array}$ & $\begin{array}{c}0.024 \\
{[0.090]}\end{array}$ & $\begin{array}{r}-0.012 \\
{[0.401]}\end{array}$ & $\begin{array}{c}0.002 \\
{[0.912]}\end{array}$ & $\begin{array}{c}0.002 \\
{[0.897]}\end{array}$ & $\begin{array}{c}0.015 \\
{[0.307]}\end{array}$ & $\begin{array}{c}0.014 \\
{[0.340]}\end{array}$ \\
\hline 10 & Net Debt & $\begin{array}{r}-0.013 \\
{[0.182]}\end{array}$ & $\begin{array}{c}0.095 \\
{[0.000]}\end{array}$ & $\begin{array}{r}-0.033 \\
{[0.001]}\end{array}$ & $\begin{array}{c}0.008 \\
{[0.402]}\end{array}$ & $\begin{array}{c}0.057 \\
{[0.000]}\end{array}$ & $\begin{array}{r}-0.010 \\
{[0.336]}\end{array}$ & $\begin{array}{r}-0.007 \\
{[0.500]}\end{array}$ & $\begin{array}{r}-0.001 \\
{[0.942]}\end{array}$ \\
\hline 11 & Free Cash Flow & $\begin{array}{c}-0.032 \\
{[0.001]}\end{array}$ & $\begin{array}{c}0.000 \\
{[0.969]}\end{array}$ & $\begin{array}{c}0.007 \\
{[0.463]}\end{array}$ & $\begin{array}{c}0.008 \\
{[0.425]}\end{array}$ & $\begin{array}{c}0.007 \\
{[0.459]}\end{array}$ & $\begin{array}{r}-0.008 \\
{[0.412]}\end{array}$ & $\begin{array}{c}0.018 \\
{[0.078]}\end{array}$ & $\begin{array}{c}0.000 \\
{[0.981]}\end{array}$ \\
\hline 12 & Premiums Paid & $\begin{array}{c}0.002 \\
{[0.828]}\end{array}$ & $\begin{array}{r}-0.006 \\
{[0.526]}\end{array}$ & $\begin{array}{c}0.011 \\
{[0.241]}\end{array}$ & $\begin{array}{r}-0.006 \\
{[0.515]}\end{array}$ & $\begin{array}{c}0.016 \\
{[0.109]}\end{array}$ & $\begin{array}{c}0.007 \\
{[0.485]}\end{array}$ & $\begin{array}{c}0.002 \\
{[0.807]}\end{array}$ & $\begin{array}{c}0.000 \\
{[0.986]}\end{array}$ \\
\hline 13 & $\begin{array}{l}\text { (Dummy) Interna- } \\
\text { tional Deal }\end{array}$ & $\begin{array}{r}-0.011 \\
{[0.242]}\end{array}$ & $\begin{array}{c}0.027 \\
{[0.006]}\end{array}$ & {$[0.000]$} & {$[0.260]$} & $\begin{array}{r}-0.009 \\
{[0.360]}\end{array}$ & $\begin{array}{r}-0.007 \\
{[0.463]}\end{array}$ & [0.590] & $\begin{array}{r}-0.001 \\
{[0.954]}\end{array}$ \\
\hline 14 & $\begin{array}{l}\text { (Dummy) Hostile } \\
\text { Deal }\end{array}$ & $\begin{array}{c}0.001 \\
{[0.953]}\end{array}$ & 0.036 & $\begin{array}{r}-0.020 \\
{[0.037]}\end{array}$ & {$[0.723]$} & {$[0.140]$} & $\begin{array}{r}-0.012 \\
{[0.220]}\end{array}$ & 0.003 & $\begin{array}{r}-0.001 \\
{[0.907]}\end{array}$ \\
\hline 15 & $\begin{array}{l}\text { (Dummy) Related } \\
\text { Deal }\end{array}$ & $\begin{array}{r}-0.001 \\
{[0.915]}\end{array}$ & $\begin{array}{c}0.047 \\
{[0.000]}\end{array}$ & $\begin{array}{r}-0.035 \\
{[0.000]}\end{array}$ & $\begin{array}{c}0.037 \\
{[0.000]}\end{array}$ & 0.059 & 0.003 & 0.016 & $\begin{array}{r}-0.011 \\
{[0.285]}\end{array}$ \\
\hline 16 & $\begin{array}{l}\text { (Dummy) With- } \\
\text { drawn Deal }\end{array}$ & $\begin{array}{r}-0.026 \\
{[0.007]}\end{array}$ & 0.079 & $\begin{array}{r}-0.058 \\
{[0.000]}\end{array}$ & $\begin{array}{c}0.059 \\
{[0.000]}\end{array}$ & 0.065 & 0.002 & 0.013 & $\begin{array}{r}-0.003 \\
{[0.797]}\end{array}$ \\
\hline 17 & $\begin{array}{l}\text { (Dummy) Public } \\
\text { Target }\end{array}$ & -0.004 & 0.020 & -0.024 & 0.012 & 0.011 & -0.008 & 0.000 & $\begin{array}{r}-0.001 \\
{[0.906]}\end{array}$ \\
\hline 18 & $\begin{array}{l}\text { Acquirer Experi- } \\
\text { ence }\end{array}$ & -0.027 & -0.048 & 0.055 & -0.032 & -0.008 & 0.098 & -0.011 & -0.007 \\
\hline
\end{tabular}


Table 2 (continued)

\begin{tabular}{|c|c|c|c|c|c|c|c|c|c|c|c|}
\hline & & & 1 & 2 & 3 & 4 & 5 & 6 & & 7 & 8 \\
\hline & & & {$[0.006]$} & {$[0.000$} & {$[0.00$} & {$[0.0$} & {$[0.4$} & 423] & $0.000]$ & {$[0.268]$} & {$[0.512]$} \\
\hline & & 9 & 10 & 11 & 12 & 13 & 14 & 15 & 16 & 17 & 18 \\
\hline 1 & CAR & & & & & & & & & & \\
\hline 2 & $\begin{array}{r}\text { Number of } \\
\text { Advisors }\end{array}$ & & & & & & & & & & \\
\hline 3 & $\begin{array}{l}\text { (Dummy) } \\
\text { One } \\
\text { Advisor }\end{array}$ & & & & & & & & & & \\
\hline 4 & $\begin{array}{c}\text { (Dummy) } \\
\text { Multiple } \\
\text { Advisors }\end{array}$ & & & & & & & & & & \\
\hline 5 & $\begin{array}{l}\text { Top Advi- } \\
\text { sor }\end{array}$ & & & & & & & & & & \\
\hline 6 & $\begin{array}{l}\text { Merger } \\
\text { Wave }\end{array}$ & & & & & & & & & & \\
\hline 7 & $\begin{array}{l}\text { Prior } \\
\text { Perfor- } \\
\text { mance }\end{array}$ & & & & & & & & & & \\
\hline 8 & $\begin{array}{c}\text { Market to } \\
\text { Book } \\
\text { Ratio }\end{array}$ & & & & & & & & & & \\
\hline 9 & $\begin{array}{c}\text { Percent } \\
\text { Cash }\end{array}$ & 1.000 & & & & & & & & & \\
\hline 10 & Net Debt & $\begin{array}{r}-0.006 \\
{[0.694]}\end{array}$ & 1.000 & & & & & & & & \\
\hline \multirow[t]{2}{*}{11} & $\begin{array}{c}\text { Free Cash } \\
\text { Flow }\end{array}$ & -0.006 & 0.001 & 1.000 & & & & & & & \\
\hline & & [0.655] & [0.915] & & & & & & & & \\
\hline \multirow[t]{2}{*}{12} & $\begin{array}{l}\text { Premiums } \\
\quad \text { Paid }\end{array}$ & 0.009 & -0.005 & 0.000 & 1.000 & & & & & & \\
\hline & & {$[0.515]$} & [0.645] & {$[0.978]$} & & & & & & & \\
\hline \multirow[t]{2}{*}{13} & $\begin{array}{l}\text { (Dummy) } \\
\text { Interna- } \\
\text { tional } \\
\text { Deal }\end{array}$ & 0.027 & 0.032 & 0.005 & -0.005 & 1.000 & & & & & \\
\hline & & {$[0.058]$} & [0.001] & [0.617] & [0.609] & & & & & & \\
\hline \multirow[t]{2}{*}{14} & $\begin{array}{c}\text { (Dummy) } \\
\text { Hostile } \\
\text { Deal }\end{array}$ & 0.015 & -0.004 & 0.001 & 0.003 & -0.007 & 1.000 & & & & \\
\hline & & [0.297] & [0.710] & [0.884] & [0.777] & [0.477] & & & & & \\
\hline \multirow[t]{2}{*}{15} & $\begin{array}{c}\text { (Dummy) } \\
\text { Related } \\
\text { Deal }\end{array}$ & -0.015 & 0.017 & -0.006 & 0.006 & 0.005 & -0.008 & 1.000 & & & \\
\hline & & {$[0.308]$} & [0.089] & [0.549] & [0.559] & {$[0.580]$} & [0.418] & & & & \\
\hline \multirow[t]{2}{*}{16} & $\begin{array}{l}\text { (Dummy) } \\
\text { With- } \\
\text { drawn } \\
\text { Deal }\end{array}$ & 0.003 & 0.013 & 0.002 & -0.001 & -0.002 & 0.018 & 0.023 & 1.000 & & \\
\hline & & [0.815] & {$[0.180]$} & [0.847] & [0.926] & [0.876] & {$[0.061]$} & [0.019] & & & \\
\hline
\end{tabular}


Table 2 (continued)

\begin{tabular}{|c|c|c|c|c|c|c|c|c|c|c|c|}
\hline & & 9 & 10 & 11 & 12 & 13 & 14 & 15 & 16 & 17 & 18 \\
\hline \multirow[t]{2}{*}{17} & (Dummy) & -0.046 & -0.006 & 0.005 & 0.048 & -0.005 & 0.153 & 0.001 & 0.018 & 1.000 & \\
\hline & & [0.001] & [0.525] & [0.587] & {$[0.000]$} & {$[0.627]$} & {$[0.000]$} & {$[0.915]$} & [0.059] & & \\
\hline \multirow[t]{2}{*}{18} & Acquirer & 0.000 & -0.014 & 0.006 & 0.019 & 0.013 & -0.011 & -0.046 & -0.042 & 0.002 & 1.000 \\
\hline & & [0.992] & [0.158] & [0.549] & [0.049] & {$[0.183]$} & {$[0.263]$} & {$[0.000]$} & {$[0.000]$} & {$[0.807]$} & \\
\hline
\end{tabular}

controls described above, such as whether the deal was hostile or friendly (Hostile), for firm $i$ in period $t$; and (4) $\varepsilon_{i t}$ is a normally distributed error term.

Because both dependents are normally distributed, we estimate this equation using an ordinary least square (OLS) model. In all cases, we control for unobserved effects, by including year dummies and acquirer industry dummies. We deal with repeated observations, in the form of the same acquirer making multiple acquisitions, by clustering by acquirer ID and target nation. Before interpreting the results, we check the base specification for multicollinearity. Using the expected performance of the deal as the dependent, for example, a variance inflation factor (VIF) test reveals that the highest VIF for a single variable is 1.03 (Leverage [log]), Experience, and Hostile Deal [dum]), with a mean of 1.02 for the base set of variables. These values are well below the established cut-offs, of 5 to 10, which are typically used to indicate multicollinearity (Hair et al. 1992; Studenmund and Cassidy 1992).

\subsection{Interviews}

We conducted three interviews with the members of an acquisitions advisory team, at one of the largest advisory firms, in Amsterdam. The interviewees described themselves as specialists in 'acquisition strategy', '(operational and financial) due diligence', and '(post-acquisition) operations integration'. Two of the three were partners. The interviews were semi-structured. The interviews aimed to gain insights into what advisors did, how they worked, and what our empirical results might mean.

\section{Results}

\subsection{Advisors per deal}

Table 2 suggests that the average acquirer in our sample employed 1.9 advisors, with a maximum of 17 advisors on the acquirer side. Table 3 provides a breakdown of the numbers. It reports that zero advisors were used in only 135 of the 10,544 acquisitions 
Table 3 Descriptive statistics and correlations

\begin{tabular}{lllll}
\hline & Mean & S.D & Min & Max \\
\hline CAR & 0.003 & 0.067 & -0.21 & 0.27 \\
Number of Advisors & 1.908 & 1.147 & 0 & 17 \\
(Dummy) One Advisor & 0.392 & 0.488 & 0 & 1 \\
(Dummy) Multiple Advisors & 0.369 & 0.482 & 0 & 1 \\
Top Advisor & 0.332 & 0.471 & 0 & 1 \\
Merger Wave & 0.631 & 0.483 & 0 & 1 \\
Prior Performance & 1.862 & 23.411 & -782.59 & 427.36 \\
Market to Book Ratio & 0.006 & 0.282 & -3.464 & 27.021 \\
Percent Cash & 79.653 & 29.633 & 0 & 100 \\
Net Debt & 760,216 & $7,697,829$ & - & $38,6000,000$ \\
Free Cash Flow & -1.623 & 152.015 & $-15,300$ & 4.719 \\
Premiums Paid & 6.676 & 700.615 & -92.94 & $71,836.51$ \\
(Dummy) International Deal & 0.176 & 0.381 & 0 & 1 \\
(Dummy) Hostile Deal & 0.019 & 0.135 & 0 & 1 \\
(Dummy) Related Deal & 0.746 & 0.435 & 0 & 1 \\
(Dummy) Withdrawn Deal & 0.048 & 0.214 & 0 & 1 \\
(Dummy) Public Target & 0.21 & 0.407 & 0 & 1 \\
Acquirer Experience & 0.677 & 1.179 & 0 & 16 \\
\hline & & & & 1 \\
\hline
\end{tabular}

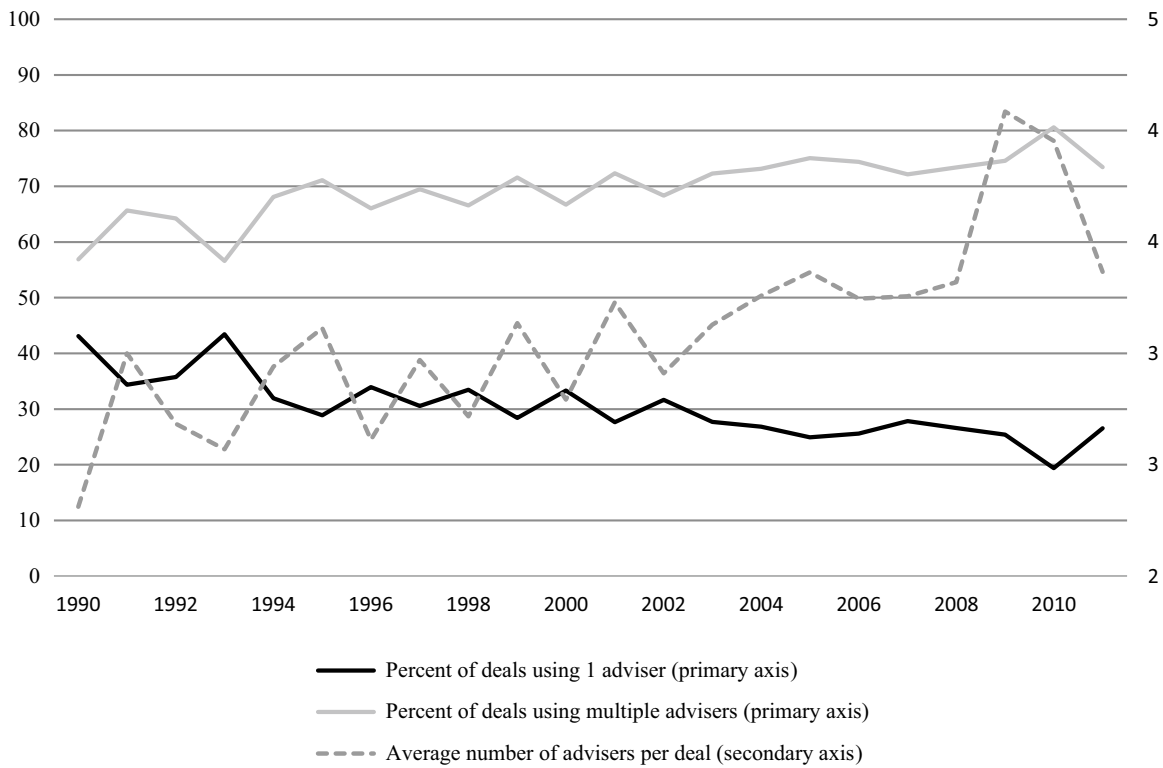

Fig. 1 Number of advisors per deal 
Table 4 Number of advisors per acquisition

\begin{tabular}{lll}
\hline Number of Advisors & Number of Cases & Percent of Cases \\
\hline 0 & 135 & 1.28 \\
1 & 4135 & 39.21 \\
2 & 4332 & 41.08 \\
3 & 1161 & 11.01 \\
4 & 431 & 4.14 \\
5 & 190 & 1.85 \\
6 & 85 & 0.80 \\
7 & 36 & 0.34 \\
8 & 13 & 0.12 \\
9 & 14 & 0.13 \\
10 & 6 & 0.05 \\
11 & 2 & 0.01 \\
12 & 1 & 0.00 \\
15 & 2 & 0.01 \\
17 & 1 & 0.00 \\
Total & 10,544 & 100 \\
\hline
\end{tabular}

$(1.2 \%),{ }^{17}$ that in slightly more than $40 \%$ of acquisitions $(n=4,135)$ one advisor was used, meaning that in a little of $58 \%$ of cases multiple advisors were used.

Figure 1 provides insights into changes in the numbers over time. It reports the percentage of acquisitions using one and multiple advisors per year. It shows that the tendency to use just one advisor fell over the period (primary axis), while the average number of advisors per deal increased (secondary axis). In 1990, the average acquisition had 2.3 advisors, and only $9.5 \%$ used 5 or more advisors, but by 2009 the average acquisitions had 4 advisors, and $38 \%$ of deals had 5 or more advisors. In other words, Fig. 1 not only shows again that most acquisitions use multiple advisors, but also that an increasing number of acquisitions use multiple advisors.

\subsection{The impact of multiple advisors}

Models $0-3$ on Table 4 consider the impact of advisors on CARs. Model 0 is the base model, which only includes the control variables. Model 1 adds the number of advisors (Number of Advisors) to this; a negative and significant coefficient $(\beta=-0.003, p=0.000)$ suggests that the number of advisors decreases expected performance. Models 2 and 3 distinguish between situations with one or multiple advisors. Model 2 uses a dummy variable to identify deals with one advisor (One Advisor) and Model 3 uses a dummy variable to identify deals with multiple advisors (Multiple Advisors). The positive and significant on One Advisor in Model $2(\beta=0.005, \mathrm{p}=0.000)$ suggests one advisor creates positive performance expectations and the negative and significant coefficient on Multiple Advisors

\footnotetext{
17 This is well below the 17\% and 19\% of acquisitions reported by Thomson in Table 1. It is likely because our sample is focused on larger US deals only.
} 
Table 5 The impact of multiple advisors

\begin{tabular}{|c|c|c|c|c|}
\hline Variables & $\begin{array}{l}\text { (1) } \\
\text { CAR }\end{array}$ & $\begin{array}{l}(2) \\
\text { CAR }\end{array}$ & $\begin{array}{l}(3) \\
\text { CAR }\end{array}$ & $\begin{array}{l}(4) \\
\text { CAR }\end{array}$ \\
\hline Number of Advisors & & $\begin{array}{l}-0.003 * * * \\
(-7.233)\end{array}$ & & \\
\hline (Dummy) One Advisor & & & $\begin{array}{l}0.005 * * * \\
(7.278)\end{array}$ & \\
\hline (Dummy) Multiple Advisors & & & & $\begin{array}{l}-0.007 * * * \\
(-13.697)\end{array}$ \\
\hline (log) Prior Performance & $\begin{array}{l}-0.000 \\
(-0.131)\end{array}$ & $\begin{array}{l}-0.000 \\
(-0.258)\end{array}$ & $\begin{array}{l}0.000 \\
(0.005)\end{array}$ & $\begin{array}{l}-0.000 \\
(-0.086)\end{array}$ \\
\hline (log) Market to Book Ratio & $\begin{array}{l}-0.001 * * \\
(-2.175)\end{array}$ & $\begin{array}{l}-0.001 * * \\
(-2.471)\end{array}$ & $\begin{array}{l}-0.001 * * \\
(-2.298)\end{array}$ & $\begin{array}{l}-0.001 * * \\
(-2.308)\end{array}$ \\
\hline (log) Percent Cash & $\begin{array}{l}0.000 \\
(1.528)\end{array}$ & $\begin{array}{l}0.000 \\
(1.426)\end{array}$ & $\begin{array}{l}0.000 \\
(1.520)\end{array}$ & $\begin{array}{l}0.000 * \\
(1.724)\end{array}$ \\
\hline$(\log )$ Net Debt & $\begin{array}{l}-0.121 * * * \\
(-8.063)\end{array}$ & $\begin{array}{l}-0.092 * * * \\
(-6.371)\end{array}$ & $\begin{array}{l}-0.112 * * * \\
(-7.503)\end{array}$ & $\begin{array}{l}-0.103 * * * \\
(-7.078)\end{array}$ \\
\hline (log) Free Cash Flow & $\begin{array}{l}0.009 \\
(0.625)\end{array}$ & $\begin{array}{l}0.008 \\
(0.579)\end{array}$ & $\begin{array}{l}0.007 \\
(0.529)\end{array}$ & $\begin{array}{l}0.012 \\
(0.816)\end{array}$ \\
\hline (log) Premiums Paid & $\begin{array}{l}0.002^{* * * *} \\
(3.488)\end{array}$ & $\begin{array}{l}0.002 * * * \\
(3.417)\end{array}$ & $\begin{array}{l}0.002 * * * \\
(3.297)\end{array}$ & $\begin{array}{l}0.002 * * * \\
(3.266)\end{array}$ \\
\hline (Dummy)International Deal & $\begin{array}{l}-0.064 \\
(-0.374)\end{array}$ & $\begin{array}{l}-0.055 \\
(-0.337)\end{array}$ & $\begin{array}{l}-0.090 \\
(-0.543)\end{array}$ & $\begin{array}{l}-0.059 \\
(-0.359)\end{array}$ \\
\hline (Dummy) Hostile Deal & $\begin{array}{l}-0.084 \\
(-0.341)\end{array}$ & $\begin{array}{l}-0.017 \\
(-0.069)\end{array}$ & $\begin{array}{l}-0.062 \\
(-0.257)\end{array}$ & $\begin{array}{l}-0.088 \\
(-0.349)\end{array}$ \\
\hline (Dummy) Related Deal & $\begin{array}{l}-0.000 \\
(-0.107)\end{array}$ & $\begin{array}{l}0.000 \\
(0.716)\end{array}$ & $\begin{array}{l}0.000 \\
(0.222)\end{array}$ & $\begin{array}{l}0.000 \\
(0.622)\end{array}$ \\
\hline (Dummy) Withdrawn Deal & $\begin{array}{l}-0.008 * * * \\
(-5.247)\end{array}$ & $\begin{array}{l}-0.007 * * * \\
(-4.169)\end{array}$ & $\begin{array}{l}-0.007 * * * \\
(-4.822)\end{array}$ & $\begin{array}{l}-0.007 * * * \\
(-4.482)\end{array}$ \\
\hline (Dummy) Public Target & $\begin{array}{l}-0.118^{*} \\
(-1.876)\end{array}$ & $\begin{array}{l}-0.103^{*} \\
(-1.800)\end{array}$ & $\begin{array}{l}-0.106 * \\
(-1.708)\end{array}$ & $\begin{array}{l}-0.110 * \\
(-1.789)\end{array}$ \\
\hline Acquisition Experience & $\begin{array}{l}-0.107 * * * \\
(-5.040)\end{array}$ & $\begin{array}{l}-0.119 * * * \\
(-5.543)\end{array}$ & $\begin{array}{l}-0.115^{* * *} \\
(-5.245)\end{array}$ & $\begin{array}{l}-0.117 * * * \\
(-5.196)\end{array}$ \\
\hline Year Dummies & Yes & Yes & Yes & Yes \\
\hline Acquirer Industry Dummies & Yes & Yes & Yes & Yes \\
\hline Clustered by Acquirer ID & Yes & Yes & Yes & Yes \\
\hline Clustered by Target Nation & Yes & Yes & Yes & Yes \\
\hline Constant & $\begin{array}{l}-0.042 * * * \\
(-11.104)\end{array}$ & $\begin{array}{l}-0.044 * * * \\
(-12.160)\end{array}$ & $\begin{array}{l}-0.049 * * * \\
(-14.670)\end{array}$ & $\begin{array}{l}-0.045^{* * *} \\
(-12.256)\end{array}$ \\
\hline Observations & 10,544 & 10,544 & 10,544 & 10,544 \\
\hline Adjusted R-squared & 0.010 & 0.013 & 0.011 & 0.013 \\
\hline
\end{tabular}

$\mathrm{t}$-statistics in parentheses

$* * * \mathrm{p}<0.01, * * \mathrm{p}<0.05, * \mathrm{p}<0.1$ 
$(\beta=-0.007, p=0.000)$ in Model 3 suggest that multiple advisors create negative performance expectations.

\subsection{Moderation effects}

Models 4-7, in Table 5 describe the hypothesized interaction effects.

Models 4 and 5 consider the effect of reputation. A positive and significant interaction term (INT: One Advisor * Top) in Model 4 suggests that top advisors, working alone, increase abnormal returns. A negative interaction term (INT: Multiple Advisor * Top) in Model 5 suggests that having top advisors on a team of advisors decreases abnormal return. Our results suggest, in other words, that top advisors deliver value and increase expected performance when working alone, but top advisors have little effect, and actually destroy deal value, when included on a team of advisors.

Models 6 and 7 then consider the effect of waves. A significant interaction term (INT: One Advisor * Wave) in Model 6 suggests that waves are opportunities for single advisors to create value. A negative and significant interaction term in Model 7 suggests that waves further reduce the expected performance of acquisitions with multiple advisors. Merger waves, in other words, are simultaneously an opportunity for acquirers with a single advisor and a threat to acquisitions with multiple advisors.

\subsection{Additional analyses}

We conduct two additional analyses:

First, and because deals with two advisors are likely to be different to those with more than two advisors, we create dummy variables to consider the market's reaction to acquisitions with zero (Zero Advisors), two (Two Advisors), three (Three Advisors), four (Four Advisors) and five (Five Advisors) advisors. We stop at five advisors because, although the deals in our sample have up to seventeen advisors, there are, in total only $160(1.5 \%)$ cases with six or more advisors. Table 6 presents the results.

Model 8 confirms the value of advisors: it reports that-compared to all acquisitions with advisors-acquisitions with zero advisors generate negative expectations ( $\beta=-0.006, p=0.000$ ). Models 9 reaffirms that acquisitions with one advisor create positive performance expectations and Models 10-13 confirm that any number of advisors above one generates a negative performance expectation. In doing so, Table 6 reaffirms our thesis that advisors create value, but multiple advisors do not. Figure 2 illustrates the relationship between CARs and the number of acquisition advisors.

Next, the SDC reports the names of the advisors involved in each acquisition. As described in the methods section, we use this data to count the number of advisors involved in each deal, and to identify top advisors. In a number of cases the SDC 
Table 6 Moderating effects of waves

\begin{tabular}{|c|c|c|c|c|}
\hline Variables & $\begin{array}{l}(5) \\
\text { CAR }\end{array}$ & $\begin{array}{l}\text { (6) } \\
\text { CAR }\end{array}$ & $\begin{array}{l}(7) \\
\text { CAR }\end{array}$ & $\begin{array}{l}\text { (8) } \\
\text { CAR }\end{array}$ \\
\hline (Dummy) One Advisor & $\begin{array}{l}0.001 * * \\
(1.193)\end{array}$ & & $\begin{array}{l}0.000 * \\
(0.542)\end{array}$ & \\
\hline Int: One Advisors x Merger Wave & $\begin{array}{l}0.004 * * * \\
(3.749)\end{array}$ & & & \\
\hline Int: One Advisor x Top Advisor & & & $\begin{array}{l}0.006 * * * \\
(6.152)\end{array}$ & \\
\hline (Dummy) Multiple Advisors & & $\begin{array}{l}-0.002 * \\
(-1.692)\end{array}$ & & $\begin{array}{l}-0.001 * * \\
(-1.826)\end{array}$ \\
\hline Int: Multiple Advisors x Merger Wave & & $\begin{array}{l}-0.003 * * \\
(-1.866)\end{array}$ & & \\
\hline Int: Multiple Advisors x Top Advisor & & & & $\begin{array}{l}-0.004 * * * \\
(-3.144)\end{array}$ \\
\hline Merger Wave & $\begin{array}{l}0.000 \\
(0.068)\end{array}$ & $\begin{array}{l}0.003^{*} \\
(1.910)\end{array}$ & & \\
\hline Top Advisor & & & $\begin{array}{l}-0.004 * * * \\
(-6.850)\end{array}$ & $\begin{array}{l}0.000 \\
(0.394)\end{array}$ \\
\hline (log) Prior Performance & $\begin{array}{l}0.001 \\
(1.395)\end{array}$ & $\begin{array}{l}0.001 \\
(1.387)\end{array}$ & $\begin{array}{l}0.001 \\
(1.372)\end{array}$ & $\begin{array}{l}0.001 \\
(1.400)\end{array}$ \\
\hline (log) Market to Book Ratio & $\begin{array}{l}-0.002 * * * \\
(-4.199)\end{array}$ & $\begin{array}{l}-0.002 * * * \\
(-4.269)\end{array}$ & $\begin{array}{l}-0.002 * * * \\
(-4.096)\end{array}$ & $\begin{array}{l}-0.002 * * * \\
(-4.163)\end{array}$ \\
\hline (log) Percent Cash & $\begin{array}{l}0.000 * * \\
(2.382)\end{array}$ & $\begin{array}{l}0.000 * * \\
(2.492)\end{array}$ & $\begin{array}{l}0.000 * * \\
(2.433)\end{array}$ & $\begin{array}{l}0.000 * * \\
(2.543)\end{array}$ \\
\hline$(\log )$ Net Debt & $\begin{array}{l}-0.144 * * * \\
(-3.836)\end{array}$ & $\begin{array}{l}-0.139 * * * \\
(-3.715)\end{array}$ & $\begin{array}{l}-0.134 * * * \\
(-3.674)\end{array}$ & $\begin{array}{l}-0.134 * * * \\
(-3.670)\end{array}$ \\
\hline (log) Free Cash Flow & $\begin{array}{l}-0.010 \\
(-1.456)\end{array}$ & $\begin{array}{l}-0.008 \\
(-1.116)\end{array}$ & $\begin{array}{l}-0.010 \\
(-1.499)\end{array}$ & $\begin{array}{l}-0.008 \\
(-1.263)\end{array}$ \\
\hline (log) Premiums Paid & $\begin{array}{l}0.000 \\
(0.296)\end{array}$ & $\begin{array}{l}0.000 \\
(0.297)\end{array}$ & $\begin{array}{l}0.000 \\
(0.256)\end{array}$ & $\begin{array}{l}0.000 \\
(0.276)\end{array}$ \\
\hline (Dummy)International Deal & $\begin{array}{l}-0.049 \\
(-0.271)\end{array}$ & $\begin{array}{l}-0.036 \\
(-0.198)\end{array}$ & $\begin{array}{l}-0.055 \\
(-0.301)\end{array}$ & $\begin{array}{l}-0.050 \\
(-0.270)\end{array}$ \\
\hline (Dummy) Hostile Deal & $\begin{array}{l}0.636 * * \\
(2.328)\end{array}$ & $\begin{array}{l}0.631 * * \\
(2.282)\end{array}$ & $\begin{array}{l}0.641 * * \\
(2.379)\end{array}$ & $\begin{array}{l}0.626 * * \\
(2.303)\end{array}$ \\
\hline (Dummy) Related Deal & $\begin{array}{l}-0.001 * \\
(-1.780)\end{array}$ & $\begin{array}{l}-0.001 * \\
(-1.713)\end{array}$ & $\begin{array}{l}-0.001 \\
(-1.626)\end{array}$ & $\begin{array}{l}-0.001 \\
(-1.520)\end{array}$ \\
\hline (Dummy) Withdrawn Deal & $\begin{array}{l}-0.005^{* * *} \\
(-3.216)\end{array}$ & $\begin{array}{l}-0.005 * * * \\
(-3.006)\end{array}$ & $\begin{array}{l}-0.005 * * * \\
(-2.924)\end{array}$ & $\begin{array}{l}-0.005 * * * \\
(-2.841)\end{array}$ \\
\hline (Dummy) Public Target & $\begin{array}{l}0.002 \\
(0.022)\end{array}$ & $\begin{array}{l}0.003 \\
(0.030)\end{array}$ & $\begin{array}{l}0.005 \\
(0.053)\end{array}$ & $\begin{array}{l}0.003 \\
(0.034)\end{array}$ \\
\hline Acquisition Experience & $\begin{array}{l}-0.162 * * * \\
(-8.562)\end{array}$ & $\begin{array}{l}-0.163 * * * \\
(-8.575)\end{array}$ & $\begin{array}{l}-0.160 * * * \\
(-8.684)\end{array}$ & $\begin{array}{l}-0.163 * * * \\
(-8.949)\end{array}$ \\
\hline Year Dummies & Yes & Yes & Yes & Yes \\
\hline Acquirer Industry Dummies & Yes & Yes & Yes & Yes \\
\hline Clustered by Acquirer ID & Yes & Yes & Yes & Yes \\
\hline Clustered by Target Nation & Yes & Yes & Yes & Yes \\
\hline Constant & $\begin{array}{l}-0.065^{* * *} \\
(-6.522)\end{array}$ & $\begin{array}{l}-0.067 * * * \\
(-7.071)\end{array}$ & $\begin{array}{l}-0.066^{* * *} \\
(-6.833)\end{array}$ & $\begin{array}{l}-0.067 * * * \\
(-6.970)\end{array}$ \\
\hline
\end{tabular}


Table 6 (continued)

\begin{tabular}{lllll}
\hline Variables & $(5)$ & $(6)$ & $(7)$ & $(8)$ \\
& CAR & CAR & CAR & CAR \\
\hline Observations & 10,544 & 10,544 & 10,544 & 10,544 \\
Adjusted R-squared & 0.009 & 0.009 & 0.009 & 0.009 \\
\hline
\end{tabular}

$\mathrm{t}$-statistics in parentheses

$* * * \mathrm{p}<0.01, * * \mathrm{p}<0.05, * \mathrm{p}<0.1$

$$
0.01
$$

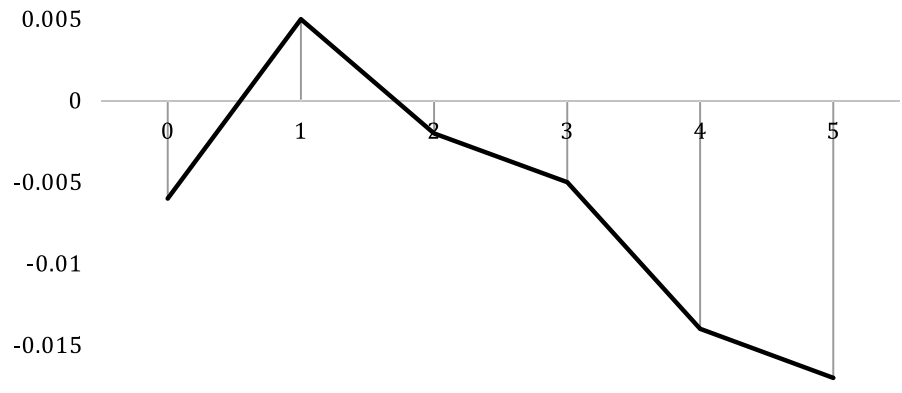

$-0.02$

Fig. 2 Number of advisors and CARs

identifies advisors as 'legal' (6611 of 10,544, or 62\%) or 'financial' (5442 of 10,544, or $51 \%$ ) advisors. Figure 3 describes the average number of each type in the period of our analysis. This variable, although incomplete, provides us with the opportunity to consider the way the market reacts to each. Table 7 reports the results. Model 14 reports that as in the 6611 cases where the number of legal advisors is reported, the number of legal advisors is negatively related to expected performance $(\beta=-0.004$, $\mathrm{p}=0.000$ ). Model 15 reports that the same is true of the 5442 cases in which the number of financial advisors is reported, although the size and significance of the effect is lower in this case $(\beta=-0.002, \mathrm{p}<0.010)$. Finally, Model 16 considered the 3743 (35\%) cases in which both the number of legal and financial advisors is reported. Interestingly, it suggests that the negative effect of the number of financial advisors vanishes when the number of legal advisors is included. Importantly, the results of Table 7 again support our thesis that as the number of advisors increases, be that in the form of legal or financial advisors, performance expectations drop (Table 8).

\subsection{Robustness checks}

We conduct a number of robustness checks.

Firstly, we confirm that results are not dependent upon our definition of the event or the estimation windows employed in the calculation of the abnormal returns. We re-estimate our models, using the other measures of abnormal returns described 


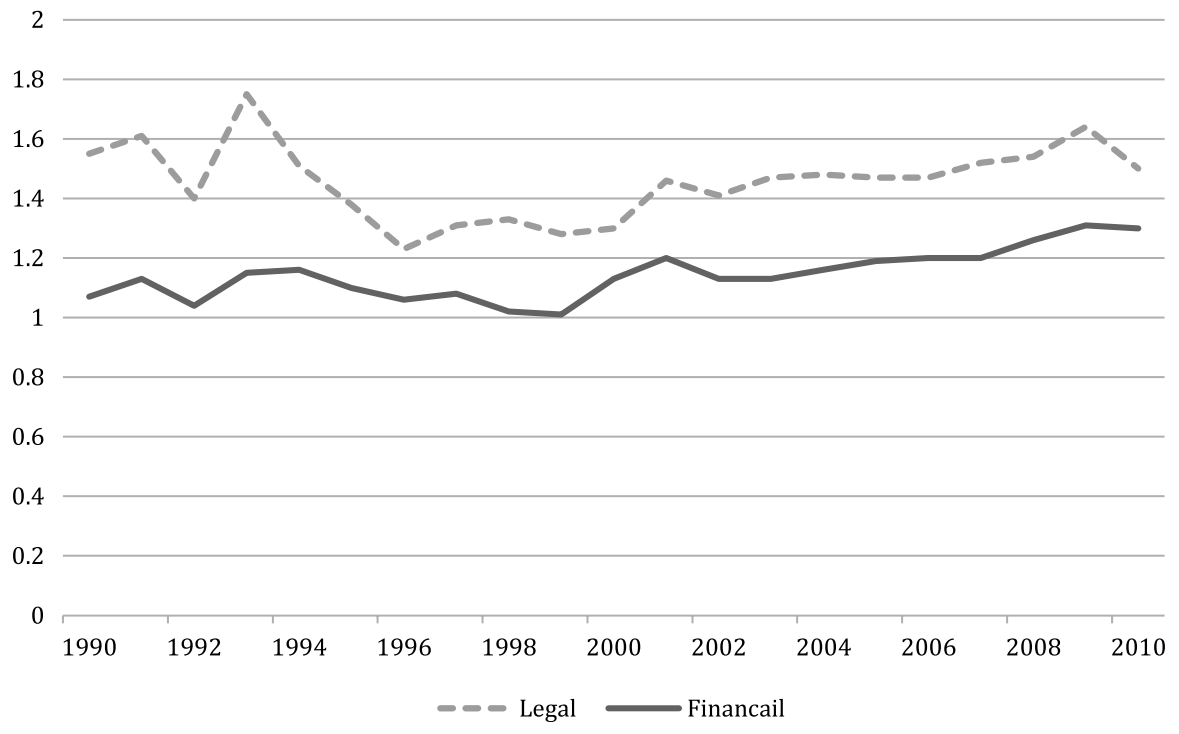

Fig. 3 Average number of financial and legal advisors per acquisition

in the methods section. The results-available upon request—support our main finding.

Second, we check our model for sample-induced endogeneity. By doing so, we aim to rule out the suggestion, raised by, for example, Servaes and Zenner, (1996) and Russo and Perrini (2006), that acquirers hire (more) advisors for complex or contentious deals, and therefore the choice between one or multiple advisors is endogenously determined. To do so, we estimate a Heckman two-stage model (Heckman 1979). In the first stage, following Van de Ven and Van Praag (1981), Shaver (1998), and Dong et al (2017), we formulate a model to explain the probability that the firm makes use of multiple advisors. We estimate this probability using: (1) Acquirer Size, measured in terms of the number of employees, to proxy acquirer size; (2) Transaction Value, measured in millions of dollars, to proxy acquisition size; (3) Number of Bidder, which is a count of the number bids made for the target, to proxy acquisition complexity and pressured; and (4) the full set of controls included in the base specification. In the second step, we then correct for self-selection by incorporating the inverse Mills ratio (IMR) as an additional explanatory variable in our estimation. We find-results available upon request - that including the IMR variable does not change our findings and therefore conclude that our findings are not driven by the fact that multiple advisors are hired in the case of big, complex, and high-risk deals.

\section{Discussion}

\subsection{Key findings \& contributions}

Our paper adds to specific discussions on advisors, on herding, on merger waves, and advisor reputation, and at the highest level, on acquisition performance. 
Table 7 The number of advisors

\begin{tabular}{|c|c|c|c|c|c|c|}
\hline \multirow[t]{2}{*}{ Variables } & (9) & (10) & (11) & (12) & (13) & (14) \\
\hline & CAR & CAR & CAR & CAR & CAR & CAR \\
\hline $\begin{array}{l}\text { (Dummy) Zero Advi- } \\
\text { sors }\end{array}$ & $\begin{array}{l}-0.006 * * * \\
(-7.974)\end{array}$ & & & & & \\
\hline (Dummy) One Advisor & & $\begin{array}{l}0.005^{* * * *} \\
(7.278)\end{array}$ & & & & \\
\hline $\begin{array}{l}\text { (Dummy) Two Advi- } \\
\text { sors }\end{array}$ & & & $\begin{array}{l}-0.002 * * * \\
(-2.890)\end{array}$ & & & \\
\hline $\begin{array}{l}\text { (Dummy) Three Advi- } \\
\text { sors }\end{array}$ & & & & $\begin{array}{l}-0.005^{* * * *} \\
(-3.139)\end{array}$ & & \\
\hline $\begin{array}{l}\text { (Dummy) Four Advi- } \\
\text { sors }\end{array}$ & & & & & $\begin{array}{l}-0.014 * * * \\
(-8.098)\end{array}$ & \\
\hline $\begin{array}{l}\text { (Dummy) Five + Advi- } \\
\text { sors }\end{array}$ & & & & & & $\begin{array}{l}-0.017 * * * \\
(-9.732)\end{array}$ \\
\hline $\begin{array}{l}\text { (log) Prior Perfor- } \\
\text { mance }\end{array}$ & $\begin{array}{l}-0.000 \\
(-0.087)\end{array}$ & $\begin{array}{l}0.000 \\
(0.005)\end{array}$ & $\begin{array}{l}-0.000 \\
(-0.138)\end{array}$ & $\begin{array}{l}-0.000 \\
(-0.030)\end{array}$ & $\begin{array}{l}-0.000 \\
(-0.087)\end{array}$ & $\begin{array}{l}-0.000 \\
(-0.376)\end{array}$ \\
\hline $\begin{array}{l}\text { (log) Market to Book } \\
\text { Ratio }\end{array}$ & $\begin{array}{l}-0.001 * * \\
(-2.099)\end{array}$ & $\begin{array}{l}-0.001 * * \\
(-2.298)\end{array}$ & $\begin{array}{l}-0.001 * * \\
(-2.165)\end{array}$ & $\begin{array}{l}-0.001 * * \\
(-2.235)\end{array}$ & $\begin{array}{l}-0.001 * * \\
(-2.308)\end{array}$ & $\begin{array}{l}-0.001 * * \\
(-2.169)\end{array}$ \\
\hline (log) Percent Cash & $\begin{array}{l}0.000 \\
(1.531)\end{array}$ & $\begin{array}{l}0.000 \\
(1.520)\end{array}$ & $\begin{array}{l}0.000 \\
(1.533)\end{array}$ & $\begin{array}{l}0.000 \\
(1.629)\end{array}$ & $\begin{array}{l}0.000 \\
(1.623)\end{array}$ & $\begin{array}{l}0.000 \\
(1.459)\end{array}$ \\
\hline$(\log )$ Net Debt & $\begin{array}{l}-0.121 * * * \\
(-8.080)\end{array}$ & $\begin{array}{l}-0.112^{* * * *} \\
(-7.503)\end{array}$ & $\begin{array}{l}-0.120 * * * \\
(-7.904)\end{array}$ & $\begin{array}{l}-0.118 * * * \\
(-8.188)\end{array}$ & $\begin{array}{l}-0.111 * * * \\
(-7.387)\end{array}$ & $\begin{array}{l}-0.111 * * * \\
(-7.638)\end{array}$ \\
\hline (log) Free Cash Flow & $\begin{array}{l}0.008 \\
(0.596)\end{array}$ & $\begin{array}{l}0.007 \\
(0.529)\end{array}$ & $\begin{array}{l}0.009 \\
(0.687)\end{array}$ & $\begin{array}{l}0.009 \\
(0.660)\end{array}$ & $\begin{array}{l}0.008 \\
(0.549)\end{array}$ & $\begin{array}{l}0.008 \\
(0.593)\end{array}$ \\
\hline (log) Premiums Paid & $\begin{array}{l}0.002 * * * \\
(3.549)\end{array}$ & $\begin{array}{l}0.002 * * * \\
(3.297)\end{array}$ & $\begin{array}{l}0.002 * * * \\
(3.457)\end{array}$ & $\begin{array}{l}0.002 * * * \\
(3.495)\end{array}$ & $\begin{array}{l}0.002 * * * \\
(3.351)\end{array}$ & $\begin{array}{l}0.002 * * * \\
(3.578)\end{array}$ \\
\hline $\begin{array}{l}\text { (Dummy)International } \\
\text { Deal }\end{array}$ & $\begin{array}{l}-0.072 \\
(-0.423)\end{array}$ & $\begin{array}{l}-0.090 \\
(-0.543)\end{array}$ & $\begin{array}{l}-0.064 \\
(-0.372)\end{array}$ & $\begin{array}{l}-0.067 \\
(-0.396)\end{array}$ & $\begin{array}{l}-0.061 \\
(-0.359)\end{array}$ & $\begin{array}{l}-0.050 \\
(-0.296)\end{array}$ \\
\hline (Dummy) Hostile Deal & $\begin{array}{l}-0.087 \\
(-0.354)\end{array}$ & $\begin{array}{l}-0.062 \\
(-0.257)\end{array}$ & $\begin{array}{l}-0.086 \\
(-0.346)\end{array}$ & $\begin{array}{l}-0.085 \\
(-0.337)\end{array}$ & $\begin{array}{l}-0.106 \\
(-0.436)\end{array}$ & $\begin{array}{l}-0.048 \\
(-0.200)\end{array}$ \\
\hline $\begin{array}{l}\text { (Dummy) Related } \\
\text { Deal }\end{array}$ & $\begin{array}{l}-0.000 \\
(-0.187)\end{array}$ & $\begin{array}{l}0.000 \\
(0.222)\end{array}$ & $\begin{array}{l}-0.000 \\
(-0.066)\end{array}$ & $\begin{array}{l}0.000 \\
(0.250)\end{array}$ & $\begin{array}{l}-0.000 \\
(-0.257)\end{array}$ & $\begin{array}{l}0.000 \\
(0.229)\end{array}$ \\
\hline $\begin{array}{l}\text { (Dummy) Withdrawn } \\
\text { Deal }\end{array}$ & $\begin{array}{l}-0.008 * * * \\
(-5.283)\end{array}$ & $\begin{array}{l}-0.007 * * * \\
(-4.822)\end{array}$ & $\begin{array}{l}-0.008 * * * \\
(-5.237)\end{array}$ & $\begin{array}{l}-0.007 * * * \\
(-4.693)\end{array}$ & $\begin{array}{l}-0.007 * * * \\
(-5.155)\end{array}$ & $\begin{array}{l}-0.008 * * * \\
(-4.997)\end{array}$ \\
\hline $\begin{array}{l}\text { (Dummy) Public } \\
\text { Target }\end{array}$ & $\begin{array}{l}-0.119^{*} \\
(-1.870)\end{array}$ & $\begin{array}{l}-0.106^{*} \\
(-1.708)\end{array}$ & $\begin{array}{l}-0.117^{*} \\
(-1.843)\end{array}$ & $\begin{array}{l}-0.114^{*} \\
(-1.900)\end{array}$ & $\begin{array}{l}-0.121^{*} \\
(-1.935)\end{array}$ & $\begin{array}{l}-0.116^{*} \\
(-1.833)\end{array}$ \\
\hline $\begin{array}{l}\text { Acquisition Experi- } \\
\text { ence }\end{array}$ & $\begin{array}{l}-0.104 * * * \\
(-4.885)\end{array}$ & $\begin{array}{l}-0.115 * * * \\
(-5.245)\end{array}$ & $\begin{array}{l}-0.108 * * * \\
(-5.019)\end{array}$ & $\begin{array}{l}-0.109 * * * \\
(-5.054)\end{array}$ & $\begin{array}{l}-0.110 * * * \\
(-5.186)\end{array}$ & $\begin{array}{l}-0.111 * * * \\
(-5.255)\end{array}$ \\
\hline Year Dummies & Yes & Yes & Yes & Yes & Yes & Yes \\
\hline $\begin{array}{l}\text { Acquirer Industry } \\
\text { Dummies }\end{array}$ & Yes & Yes & Yes & Yes & Yes & Yes \\
\hline $\begin{array}{l}\text { Clustered by Acquirer } \\
\text { ID }\end{array}$ & Yes & Yes & Yes & Yes & Yes & Yes \\
\hline $\begin{array}{l}\text { Clustered by Target } \\
\text { Nation }\end{array}$ & Yes & Yes & Yes & Yes & Yes & Yes \\
\hline
\end{tabular}


Table 7 (continued)

\begin{tabular}{lllllll}
\hline Variables & $(9)$ & $(10)$ & $(11)$ & $(12)$ & $(13)$ & $(14)$ \\
& CAR & CAR & CAR & CAR & CAR & CAR \\
\hline Constant & $-0.041^{* * *}$ & $-0.049 * * *$ & $-0.042^{* * *}$ & $-0.043 * * *$ & $-0.043 * * *$ & $-0.044 * * *$ \\
& $(-5.099)$ & $(-5.850)$ & $(-5.143)$ & $(-5.248)$ & $(-5.312)$ & $(-11.345)$ \\
Observations & 10,544 & 10,544 & 10,544 & 10,544 & 10,544 & 10,544 \\
Adjusted R-squared & 0.010 & 0.011 & 0.010 & 0.011 & 0.012 & 0.011 \\
\hline
\end{tabular}

$\mathrm{t}$-statistics in parentheses

$* * * \mathrm{p}<0.01, * * \mathrm{p}<0.05, * \mathrm{p}<0.1$

We contribute to the literature on acquisitions advisors by quantifying the number of deals that use multiple advisors. To date, only a few studies within this literature (e.g., Hunter and Jagtiani 2003; Rasedie and Srinivasan 2011) have acknowledged that acquirers can make use of multiple advisors. We not only show that almost $60 \%$ of deals are concluded with the aid of multiple advisors, but we find the share of deals making use of more than one advisors increased in the period of our study. This fact-especially when coupled with our empirical finding on the implications of using one or multiple advisors-suggests that contrasting deals with and without advisors, as this literature has traditionally tended to do, is neither correct nor sufficient.

Secondly, we contribute to the literature on advisors by showing that the effect of advisors is contingent on the numbers employed. We find that acquisitions that employ one advisor have a higher expected performance than deals with no advisors. In so doing, we vindicate both the advisory industry and the decision of managers to hire advisors for their acquisitions. We find, however, that more advisors drive down performance and suggest that this is because they fall victim to wellknown 'cheap talk' mechanisms. In so doing, we connect the literature on advisors with that on cheap talk, and support the idiom that 'too many cooks spoil the broth'. We conclude that advisors can add value, but that it is the way in which multiple advisors interact that is likely to be the cause of any problem. This is an important contribution, for scholars, looking to make sense of the mixed evidence on the role of advisors in acquisitions, and for managers, looking to maximize value through acquisitions.

Zooming in on herding-which is an important concept within both the acquisitions- and the cheap talk literature-we make two additional contributions. First, we contribute to the discussion, within the literature on advisors, on the impact of advisor quality This literature has long presented mixed results (e.g., Bowers and Miller, 1990; Servaes and Zenner 1996; Rau 2000; Ismail 2010; Rasedie and Srinivasan 2011). In line with the suggestions of the cheap talk theory, however, we find that effect of including a top advisor is conditional on the number of advisors: single top advisors deliver value, while teams with top advisors have little effect.

Then, our discussion of advisors in the context of a merger way contributes to both the literature on advisors and the literature on merger waves. By linking these literatures, we not only demonstrate that the effects of advisors vary by the context 
Table 8 The type of advisors

\begin{tabular}{|c|c|c|c|}
\hline Variables & $\begin{array}{l}(15) \\
\text { CAR }\end{array}$ & $\begin{array}{l}(16) \\
\text { CAR }\end{array}$ & $\begin{array}{l}(17) \\
\text { CAR }\end{array}$ \\
\hline Number of Legal Advisors & $\begin{array}{l}-0.004 * * * \\
(-6.474)\end{array}$ & & $\begin{array}{l}-0.004 * * * \\
(-5.937)\end{array}$ \\
\hline Number of Financial Advisors & & $\begin{array}{l}-0.002^{*} \\
(-1.678)\end{array}$ & $\begin{array}{l}0.000 \\
(0.028)\end{array}$ \\
\hline (log) Prior Performance & $\begin{array}{l}-0.000 \\
(-0.802)\end{array}$ & $\begin{array}{l}-0.000 \\
(-0.523)\end{array}$ & $\begin{array}{l}-0.002 * * \\
(-2.106)\end{array}$ \\
\hline (log) Market to Book Ratio & $\begin{array}{l}-0.000 * \\
(-1.826)\end{array}$ & $\begin{array}{l}-0.002^{* * *} \\
(-5.571)\end{array}$ & $\begin{array}{l}-0.003 * * * \\
(-8.467)\end{array}$ \\
\hline (log) Percent Cash & $\begin{array}{l}-0.000 \\
(-0.792)\end{array}$ & $\begin{array}{l}0.000 \\
(0.764)\end{array}$ & $\begin{array}{l}0.000 \\
(0.146)\end{array}$ \\
\hline$(\log )$ Net Debt & $\begin{array}{l}-0.029 \\
(-1.169)\end{array}$ & $\begin{array}{l}-0.160 * * * \\
(-6.083)\end{array}$ & $\begin{array}{l}-0.105^{* * * *} \\
(-3.587)\end{array}$ \\
\hline (log) Free Cash Flow & $\begin{array}{l}0.001 \\
(0.064)\end{array}$ & $\begin{array}{l}0.036 * * * \\
(2.631)\end{array}$ & $\begin{array}{l}0.018 \\
(1.147)\end{array}$ \\
\hline (log) Premiums Paid & $\begin{array}{l}0.003 * * * \\
(5.083)\end{array}$ & $\begin{array}{l}0.001 \\
(0.772)\end{array}$ & $\begin{array}{l}0.000 \\
(0.397)\end{array}$ \\
\hline (Dummy)International Deal & $\begin{array}{l}0.113 \\
(0.650)\end{array}$ & $\begin{array}{l}-0.038 \\
(-0.206)\end{array}$ & $\begin{array}{l}0.126 \\
(0.404)\end{array}$ \\
\hline (Dummy) Hostile Deal & $\begin{array}{l}-0.057 \\
(-0.188)\end{array}$ & $\begin{array}{l}0.135 \\
(0.573)\end{array}$ & $\begin{array}{l}0.115 \\
(0.887)\end{array}$ \\
\hline (Dummy) Related Deal & $\begin{array}{l}0.000 \\
(0.363)\end{array}$ & $\begin{array}{l}0.000 \\
(0.200)\end{array}$ & $\begin{array}{l}0.000 \\
(0.081)\end{array}$ \\
\hline (Dummy) Withdrawn Deal & $\begin{array}{l}-0.006^{* * * *} \\
(-3.394)\end{array}$ & $\begin{array}{l}-0.005^{* * * *} \\
(-3.982)\end{array}$ & $\begin{array}{l}-0.002 \\
(-1.088)\end{array}$ \\
\hline (Dummy) Public Target & $\begin{array}{l}0.024 \\
(0.294)\end{array}$ & $\begin{array}{l}0.032 \\
(0.360)\end{array}$ & $\begin{array}{l}0.062 \\
(0.642)\end{array}$ \\
\hline Acquisition Experience & $\begin{array}{l}-0.027 * \\
(-1.714)\end{array}$ & $\begin{array}{l}-0.138 * * \\
(-2.471)\end{array}$ & $\begin{array}{l}0.002 \\
(0.034)\end{array}$ \\
\hline Year Dummies & Yes & Yes & Yes \\
\hline Acquirer Industry Dummies & Yes & Yes & Yes \\
\hline Acquirer ID & Yes & Yes & Yes \\
\hline Target Nation & Yes & Yes & Yes \\
\hline Constant & $\begin{array}{l}-0.147 * * * \\
(-27.298)\end{array}$ & $\begin{array}{l}0.187 * * * \\
(22.399)\end{array}$ & $\begin{array}{l}0.041^{* * * *} \\
(4.717)\end{array}$ \\
\hline Observations & 6611 & 5442 & 3743 \\
\hline Adjusted R-squared & 0.004 & 0.010 & 0.005 \\
\hline
\end{tabular}

$\mathrm{t}$-statistics in parentheses

$* * * \mathrm{p}<0.01, * * \mathrm{p}<0.05, * \mathrm{p}<0.1$

in which they operate, but we open new research opportunities for scholars of both advisors and merger waves. We find, in line, again, with cheap talk theory, that the negative effect of multiple advisors is exaggerated in the context of merger waves, but we find that there are no moderating effects in the context of a single advisor. 
Next, while most of the literature has looked at the impact of financial advisors (e.g., Rau 2000; Allen et al. 2004; Francis et al. 2006; Bao and Edmans 2011; Ismail 2010; Rasedie and Srinivasan 2011), "we [still] know little about how lawyers affect acquisitions" (Karsten et al. 2015, p2). We add to the limited literature on the empirical impact of legal advisors, and to the limited number of studies that consider both legal and financial advisors (see e.g., Russo and Perrini 2006). We show that the number of the different types of advisors has moderately different effects, but find that, irrespective of type, the rule remains the same: too many cooks spoil the broth.

Finally, we contribute to the general acquisition literature by providing insight on market reactions to acquisition announcements, the value of acquisition advisors, and the conditions under which they create positive expectations of value creation.

\subsection{Managerial implications}

We analyse market reactions to the announcement of 10,544, large, US acquisitions. Our results provide managers, of similar firms, with three real-world insights.

First, managers should hire an advisor. Our results suggest that acquirers that hire an advisor outperform acquirers that do not hire an advisor. We find evidence too that those that hire a top advisor, and those that hiring one in a merger wave, create value. Our data suggests that advisors really do have specialist skills and, according to our analysis, these skills really do create and deliver value for acquirers.

Second, managers should know that, when it comes to advisors, 'too many cooks spoil the broth'. We find that expected performance drops steeply, increasing from one advisor to two, to three, and so on. Importantly, we suggest that this is not due to any agency on the advisors' behalf, but simply due to the dynamics that emerge when people work together. The implication however is simple: one is better than two. We find evidence that hiring a second advisor negates the positive value of having a top-quality advisor. We also find that while it seems like 'two heads might be better than one' in the context of a fast-moving, high-pressure merger wave, our results suggest that multiple advisors in a merger wave destroy expected more acquisition value.

Finally, and putting all of this together, the implication is that managers could and should be able to save billions on unnecessary advisory fees. In our sample, the average deal had 1.88 advisors. Observers estimate thatthe advisory industry earns something in the region of $\$ 40$ billion per year on acquisitions. ${ }^{18}$ Our findings suggest that as much as half of this is not being used to create value and could be saved.

\footnotetext{
18 Annual estimates based on Thomson Reuter's half-yearly estimates, as reported here: http://prod-uppimage-read.ft.com/3b08df8e-cf53-11e8-a9f2-7574db66bcd5
} 


\section{Limitations}

All research has its limitations. In this section, we discuss our main research limitations and explore the research opportunities that they imply. We highlight six, in particular, related to the empirical setting, methods, and the assumptions we make.

First, we only study large ( $>\$ 10$ million) deals by US acquirers. We do this simply for reasons of data availability and to ensure comparability. We recognise, however, that large deals by US acquirers are providing a relatively unique institutional context, which raises questions as to the generalizability of our findings outside of this setting. At the very least, research suggests that acquisitions by smaller and larger firms perform differently (Moeller et al. 2005; Weitzel and McCarthy 2011). We hope that future research will test our hypotheses in other institutional contexts.

Second, we use an event study to describe expected performance or expected value-creation. We do this because the event study is a corner-stone tool in strategy (Schijven and Hitt 2012). We recognize, however, that the assumption that markets can correctly incorporate new information, and accurately update the expected value of the firm, has been challenged (e.g., Grossman and Stiglitz 1980) in finance (e.g., Shleifer 2000) and strategy (e.g., Cording et al. 2010). It is well-known that abnormal returns are not only influenced by cognitive biases (Ozcan and Overby 2008), but also by factors that affect moods, such as good weather (Hirshleifer and Shumway 2003) and bad news (Kaplanski and Levy 2010). As a result, expected performance does not always predict long-term performance (Zollo and Meier 2008). It would be interesting for future research to examine the effects which we document, in terms of short-term reactions, using a longer-term performance measure.

Third, we consider the way in which the market reacts to the announcement of acquisitions with differing numbers of advisors, without considering what the advisors are doing, or how they are working, in any real sense. Two advisors, for example, that split the work are likely to have a different effect to two advisors that work together, and two advisors that work sequentially are likely to have a different effect again. In this study, we do not account for any of this variation. It would be interesting for future research to examine the way in which the advisors work, and the way that this not only affects expected performance but for actual performance too.

Fourth, we make a number of assumptions regarding the way in which the managers and the advisors interact. For example, we assume that the contribution of individual advisors cannot be fully discerned, and we assume that managers can continue to hire advisors sequentially. We do this because existing quantitative literature on merger advisor selection tends to be based on secondary data-and consequently, not very process-oriented-and in-depth qualitative-oriented studies on the process of choosing advisors are rare. We call on future researchers to better map the hiring process and use this insight to enrich the analyses that we conduct in this paper.

Fifth, we observe that the targets in our sample also use advisors, but ignore that fact in this study. In reality, however, advisors on the target and theacquirers side might interact in interesting and important ways. For example, different divisions 
of the same advisory firms are often engaged on opposing sides of the table', by the target and the acquirer. ${ }^{19}$ It would be interesting to explore the role and effect of the advisors of the target, on the process, on the acquirer's advisors, and overall value-creation.

Finally, we control for acquisition risk, in terms of size, hostility, and (un)relatedness, but we assume that the strategy underlying all acquisitions is the same. There is evidence to suggest, however, that the risks and uncertainty contained in a costcutting acquisition are significantly different from those in a revenue-expanding acquisition (e.g., Devos et al. 2009; Rabier 2017; Aalbers et al. 2021). The negative effect of multiple advisors may be moderated by the acquisition motive. We hope that future research will consider the impact of advisors in different strategic contexts.

\section{Conclusion}

At US\$3.6 trillion, the 2020 merger market was about equal to the German economy (US\$3.8 trillion). Advisors pocketed something in the region of $1 \%$ of this.

Advisors are hired because mergers and acquisitions are complex events, which are subject to risk, uncertainty, and information asymmetry. Advisors, the literature suggests, are able to identify better deals, meaning that better deals get made, they are better negotiators, meaning that their clients capture a greater share of the value, they possess experience and specialist knowledge, meaning that they can generate greater synergies at a lower cost, and they reduce the information asymmetries, between the target and the acquirer, and between managers, shareholders and investors.

In spite of this, the academic literature has largely rejected a value-enhancing role for advisors; it shows that advisors have zero or a negative effect on performance, and because of this, advisors have been cast as guileful, manipulative, and self-serving.

The existing discussion has, however, largely ignored the empirical reality that the vast majority of deals are completed with the aid of multiple advisors. In this paper, and using the insights from the "cheap talk" literature, we considered the dynamics of a deal with one or more advisors. We argued that one advisor would benefit an acquisition, but multiple would harm it. We then extended our discussion to consider the moderating role of including top advisors - arguing that reputation should only play a role in the context of a single advisor-and merger waves-arguing that herd behavior is more likely to be problematic in the context of multiple advisors.

Using data on 10,544 large US acquisitions, we empirically support both a valuecreating and value-destroying function for advisors. We show that it is the number that matters. We support the proposition, therefore, that advisors can and do add value - in the sense that deals with one advisor generate higher performance

${ }^{19}$ From the set of interviews, with M\&A advisors, conducted for this research. 
expectations-but show that 'too many cooks spoil the broth'. In so doing, we contribute to the discussion of advisors, and the roles of reputation and merger waves on performance. We also provide practical insights for managers, who may wonder if advisors are worth it and, if they are, if one can have too much of a good thing.

Open Access This article is licensed under a Creative Commons Attribution 4.0 International License, which permits use, sharing, adaptation, distribution and reproduction in any medium or format, as long as you give appropriate credit to the original author(s) and the source, provide a link to the Creative Commons licence, and indicate if changes were made. The images or other third party material in this article are included in the article's Creative Commons licence, unless indicated otherwise in a credit line to the material. If material is not included in the article's Creative Commons licence and your intended use is not permitted by statutory regulation or exceeds the permitted use, you will need to obtain permission directly from the copyright holder. To view a copy of this licence, visit http://creativecommons.org/licen ses/by/4.0/.Open Access This article is licensed under a Creative Commons Attribution 4.0 International License, which permits use, sharing, adaptation, distribution and reproduction in any medium or format, as long as you give appropriate credit to the original author(s) and the source, provide a link to the Creative Commons licence, and indicate if changes were made. The images or other third party material in this article are included in the article's Creative Commons licence, unless indicated otherwise in a credit line to the material. If material is not included in the article's Creative Commons licence and your intended use is not permitted by statutory regulation or exceeds the permitted use, you will need to obtain permission directly from the copyright holder. To view a copy of this licence, visit http://creativecommons.org/licenses/by/4.0/.

\section{References}

Aalbers HL, McCarthy KJ, Heiimeriks KH (2021) Market reactions to acquisition announcements: the importance of signalling 'why' and 'where'. Long Range Planning (Forthcoming)

Agrawal A, Cooper T, Lian Q, Wang Q (2011) The impact of common advisors on mergers and acquisitions. ISSRN 1787272.

Allen L, Jagtiani J, Peristiani S, Saunders A (2004) The role of bank advisors in mergers and acquisitions. J Money, Credit, Bank 36:197-224

Angwin D (2001) Mergers and acquisitions across European borders: National perspectives on preacquisition due diligence and the use of professional advisors. J World Bus 36:32-57

Asquith P (1983) Merger bids, uncertainty, and stockholder returns. J Financ Econ 11:51-83

Bao J, Edmans A (2011) Do investment banks matter for M\&A returns? Rev Financ Stud 24(7):2286-2315

Battaglini M (2004) Policy advice with imperfectly informed experts. Adv Theor Econ 4(1):1-32

Becher D, Cai J, Ouyang W (2010) Do shareholders listen? M\&A advisor opinions and shareholder voting. Working Paper, Drexel University.

Becher DA, Juergens JL (2010) M\&A advisory fees and analyst conflicts of interest. University of TexasAustin working paper.

Betton S, Eckbo BE (2000) Toeholds, bid jumps, and expected payoffs in takeovers. Rev Financ Stud 13(4):841-882

Bharadwaj A, Shivdasani A (2003) Valuation effects of bank financing in acquisitions. J Financ Econ 67(1):113-148

Bourjade S, Jullien B (2011) The roles of reputation and transparency on the behaviour of biased experts. Rand J Econ 42(3):575-594

Bowman C, Fuller K, Nain A (2009) Market valuation and acquisition quality: empirical evidence. Rev Financ Stud 22(2):633-679

Browers HM, Miller RE (1990) Choice of investment banker and shareholders' wealth of firms involved in acquisitions. Financ Manage 19(4):34-44

Brown SJ, Warner JB (1985) Using daily stock returns. J Financ Econ 14(1):3-31 
Cain M, Denis D (2008) Do fairness opinion valuation analyses contain useful information. Purdue University Working Paper.

Chatterjee S (1986) Types of synergy and economic value: the impact of acquisitions on merging and rival firms. Strateg Manag J 7(2):119-139

Conn RL, Cosh A, Guest PM, Hughes A (2005) The impact on UK acquirers of domestic, cross-border, public and private acquisitions. J Bus Financ Acc 32(5-6):815-870

Cording M, Christmann P, Weigelt C (2010) Measuring theoretically complex constructs: the case of acquisition performance. Strateg Organ 8(1):11-41

Crawford VP, Sobel J (1982) Strategic information transmission. Econ J Econ Soc 50(6):1431-1451

Da Silva Rosa R, Lee P, Scott M, Walter T (2004) Competition in the market for takeover advisors. Aust J Manag 29:61-92

De Jong A, Ongena S, Van Der Poel M (2008) Thinking about going abroad: the choice of advisor in cross-border M\&A deals. In EFA 2008 Athens Meetings Paper.

Devos E, Kadapakkam PR, Krishnamurthy S (2009) How do mergers create value? A comparison of taxes, market power, and efficiency improvements as explanations for synergies. Rev Financ Stud 22(3):1179-1211

Diamond PA, Maskin E (1979) An equilibrium analysis of search and breach of contract, I: Steady states. Bell J Econ 10(1):282-316

Dong JQ, McCarthy KJ, Schoenmakers WW (2017) How central is too central? Organizing interorganizational collaboration networks for breakthrough innovation. J Prod Innov Manag 34(4):526-542

Doukas JA, Zhang W (2016) Envy-motivated merger waves. Eur Financ Manag 22(1):63-119

Eccles RG, Crane DB (1988) Doing deals: Investment banks at work. Harvard Business School Press, Boston, MA

Francis B, Hasan I, Sun X (2006) How do firms choose financial advisors in mergers and acquisitions and why do they switch? Mimeo, Rensselaer Polytechnic Institute

Goel AM, Thakor AV (2010) Do envious CEOs cause merger waves? Rev Financ Stud 23(2):487-517

Grossman SJ, Hart OD (1980) Takeover bids, the free-rider problem, and the theory of the corporation. Bell J Econ 11(1):42-64

Grossman SJ, Stiglitz JE (1980) On the impossibility of informationally efficient markets. Am Econ Rev 70(3):393-408

Hair J, Anderson R, Tatham R, Black W (1992) Multivariate data analysis. Macmillan, New York, NY

Haleblian J, Finkelstein S (1999) The influence of organizational acquisition experience on acquisition performance: a behavioural learning perspective. Adm Sci Q 44(1):29-56

Hayward ML (2003) Professional influence: The effects of investment banks on clients' acquisition financing and performance. Strateg Manag J 24(9):783-801

Heckman J (1979) Sample selection bias as a specification error. Econometrica 47(1):153-216

Hirshleifer D, Shumway T (2003) Good day sunshine: stock returns and the weather. J Finance 58(3):1009-1032

Hunter WC, Jagtiani J (2003) An analysis of advisor choice, fees, and effort in mergers and acquisitions. Rev Financ Econ 12:65-81

Hunter WC, Walker M (1990) An empirical explanation of investment banking merger fee contracts. South Econ J 56:1117-1130

Ishida J, Shimizu T (2012) Asking one too many? Why leaders need to be decisive, ISER Discussion Paper No, p 857

Ismail A (2010) Are good financial advisors really good? The performance of investment banks in the M\&A market. Rev Quant Financ Acc 35(4):411-429

Jensen M (1986) Agency costs of free cash flow, corporate finance, and takeovers. Am Econo Rev 76(2):323-329

Kale J, Kini O, Ryan H (2003) Financial advisors and shareholder wealth gains in corporate takeovers. J Financ Quant Anal 38:475-501

Kaplanski G, Levy H (2010) Sentiment and stock prices: the case of aviation disasters. J Financ Econ 95(2):174-201

Karsten C, Malmendier U, Sautner Z (2015) M\&A negotiations and lawyer expertise. SSRN 2576866.

King DR, Dalton DR, Daily CM, Covin JG (2004) Meta-analyses of post-acquisition performance: indications of unidentified moderators. Strateg Manag J 25(2):187-200

King DR, Wang G, Samimi M, Cortes AF (2020) A meta-analytic integration of acquisition performance prediction. J Manag Stud. 
Kisgen D, Qian J, Song W (2009) Are fairness opinions fair? The case of mergers and acquisitions. J Financ Econ 91:179-207

Kolasinski AC, Kothari SP (2008) Investment banking and analyst objectivity: evidence from analysts affiliated with mergers and acquisitions advisors. J Financ Quant Anal 43(4):817-842

Kosnik RD, Shapiro DL (1997) Agency conflicts between investment banks and corporate clients in merger and acquisition transactions: causes and remedies. Acad Manag Exec 11(1):7-20

Krishna V, Morgan J (2001) A model of expertise. Quart J Econ 116(2):747-775

Krishnan CNV, Masulis RW (2011) Venture capital reputation: a survey. The Oxford Handbook of Venture Capital, Douglas J. Cummings, ed., Oxford University Press, 2011

Lavallo D, Kahnemann D (2003) Harv Bus Rev 81(7):56-63

Li M (2010) Advice from multiple experts: a comparison of simultaneous, sequential, and hierarchical communication. BE J Theor Econ 10(1):18

Ma Q (2007) Mergers and investment banks: How do banks help targets? Cornell University, Mimeo

MacKinley AC (1997) Event studies in economics and finance. J Econ Literat 35(1):13-39

Malmendier U, Tate G (2008) Who makes acquisitions? CEO overconfidence and the market's reaction. J Financ Econ 89(1):20-43

Martynova M, Renneboog L (2008) A century of corporate takeovers: What have we learned and where do we stand? J Bank Finance 32(10):2148-2177

McCarthy KJ, Aalbers HL (2016) Technological acquisitions: the impact of geography on post-acquisition innovative performance. Res Policy 45(9):1818-1832

McCarthy KJ, Dolfsma W, Weitzel U (2016) The first global merger wave and the enigma of Chinese performance. Manag Organ Rev 12(02):221-248

McLaughlin RM (1990) Investment banking contracts in tender offers: an empirical analysis. J Financ Econ 28:209-232

McLaughlin RM (1992) Does the form of compensation matter? Investment banker fee contracts in tender offers. J Financ Econ 32:223-260

McNamara G, Haleblain J, Dykes B (2008) The performance implications of participating in an acquisition wave: Early mover advantages, bandwagon effects, and the moderating influence of industry characteristics and acquirer tactics. Acad Manag J 51:113-130

McWilliams A, Siegel D (1997) Event studies in management research: theoretical and empirical issues. Acad Manag J 40(3):626-657

Michel A, Shaked I, Lee Y (1991) An evaluation of investment banker acquisition advice: the shareholders' perspective. Financ Manage 20:40-49

Moeller S, Schlingemann F, Stulz R (2005) Wealth destruction on a massive scale? A study of acquiring firm returns in the recent merger wave. J Finance 60(2):757-782

Mullainathan S, Shleifer A (2005) The market for news. Am Econ Rev 95(1):1031-1053

Ottaviani M, Sørensen PN (2006) Professional advice. J Econ Theory 126(1):120-142

Ozcan S, Overby ML (2008) A cognitive model of stock market reactions to multi-firm alliance announcements. Strateg Organ 6(4):435-469

Rabier MR (2017) Acquisition motives and the distribution of acquisition performance. Strateg Manag J 38(13):2666-2681

Rasedie K, Srinivasan G (2011) Investment bank market share and the performance of acquiring companies: Canadian evidence. J Comp Int Manag 14(1):26-51

Rau PR, Rodgers KJ (2002) Do bidders hire top-tier investment banks to certify value? Working Paper, Purdue University, and Penn State University

Rau PR (2000) Investment bank market share, contingent fee payments, and the performance of acquiring firms. J Financ Econ 56:293-324

Rau PR, Vermaelen T (1998) Glamour, value and the post-acquisition performance of acquiring firms. J Financ Econ 49(2):223-253

Rhodes-Kropf M, Viswanathan S (2004) Market valuation and merger waves. J Financ 59(6):2685-2718

Roll R (1986) The hubris hypothesis of corporate takeovers. J Bus 59:197-216

Russo A, Perrini F (2006) The real cost of M\&A advice. Eur Manag J 24(1):49-58

Scharfstein, D.S., Stein, J.C., 1990. Herd behaviour and investment. The American Economic Review,465-479.

Schenk H (1996) Bandwagon mergers, international competitiveness, and government policy. Empirica 23(3):255-278

Schijven M, Hitt MA (2012) The vicarious wisdom of crowds: Toward a behavioral perspective on investor reactions to acquisition announcements. Strateg Manag J 33(11):1247-1268 
Servaes H, Zenner M (1996) The role of investment banks in acquisition. The Reivew of Financial Services 9(3):787-815

Shaver JM (1998) Accounting for endogeneity when assessing strategy performance: Does entry mode choice affect FDI survival? Manage Sci 44(4):571-586

Shleifer A (2000) Inefficient markets. Oxford University Press, New York

Studenmund AH, Cassidy HJ (1992) Instructor's manual to accompany Using econometrics: a practical guide. Harper Collins Publications, New York

Thomas HA (1995) The effects of firm ownership structure on hiring of M\&A advisors. J Financ Serv Res 9:159-175

Van de Ven WP, Van Praag BM (1981) The demand for deductibles in private health insurance: a probit model with sample selection. J Econ 17(2):229-252

Walter T, Yawson A, Yeung C (2005) Does a quality premium exist in M\&A advisory fees. University of New South Wales working paper.

Weitzel U, McCarthy KJ (2011) Theory and evidence on mergers and acquisitions by small and medium enterprises. Int J Entrep Innov Manag 14(2-3):248-275

Welch X, Pavićević S, Keil T, Laamanen T (2020) The pre-deal phase of mergers and acquisitions: a review and research agenda. J Manag 46(6):843-878

Zaheer S (1995) Overcoming the liability of foreignness. Acad Manag J 38(2):341-363

Zapechelnyuk A (2013) Eliciting information from a committee). J Econ Theory 148(5):2049-2067

Zollo M, Meier D (2008) What is M\&A performance? Acad Manag Perspect 22(3):55-77

Publisher's Note Springer Nature remains neutral with regard to jurisdictional claims in published maps and institutional affiliations. 